\title{
Management strategies for the treatment and prevention of postoperative/postdischarge nausea and vomiting: an
} updated review [version 1; peer review: 2 approved]

\author{
Ofelia Loani Elvir-Lazo (D1) Paul F. White (iD)1-3, Roya Yumul11,4, Hillenn Cruz Eng 5 \\ ${ }^{1}$ Department of Anesthesiology, Cedars-Sinai Medical Center, Los Angeles, CA, 90048, USA \\ ${ }^{2}$ The White Mountain Institute, The Sea Ranch, Sonoma, CA, 95497, USA \\ ${ }^{3}$ Instituto Ortopedico Rizzoli, University of Bologna, Bologna, Italy \\ ${ }^{4}$ David Geffen School of Medicine-UCLA, Charles R. Drew University of Medicine and Science, Los Angeles, CA, 90095, USA \\ ${ }^{5}$ Department of Anesthesiology, PennState Hershey Medical Center, Hershey, PA, 17033, USA
}

V1 First published: 13 Aug 2020, 9(Faculty Rev):983
https://doi.org/10.12688/f1000research.21832.1

https://doi.org/10.12688/f1000research.21832.1

https://doi.org/10.12688/f1000research.21832.1

\section{Open Peer Review}

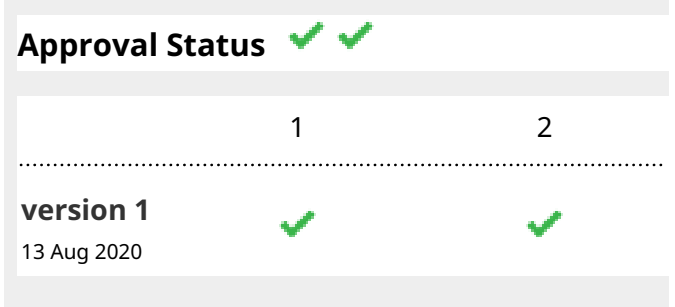

Faculty Reviews are review articles written by the prestigious Members of Faculty Opinions. The articles are commissioned and peer reviewed before publication to ensure that the final, published version is comprehensive and accessible. The reviewers who approved the final version are listed with their names and affiliations.
1. Patrice Forget ID, University of Aberdeen, Aberdeen, UK

2. Joseph V. Pergolizzi, Naples Anesthesia and Pain Associates - Pain Medicine, Naples, USA Any comments on the article can be found at the end of the article. 


\section{Keywords}

Postoperative nausea and vomiting (PONV), Postdischarge nausea and vomiting (PDNV), Retching, Multimodal antiemetic therapy, Antiemetic drugs, Aromatherapy, Non-pharmacologic antiemetic therapies, Neiguan point (PC6).

Corresponding author: Paul F. White (Paul.White@cshs.org)

Author roles: Elvir-Lazo OL: Conceptualization, Investigation, Project Administration, Resources, Writing - Original Draft Preparation, Writing - Review \& Editing; White PF: Writing - Original Draft Preparation, Writing - Review \& Editing; Yumul R: Supervision, Writing Original Draft Preparation, Writing - Review \& Editing; Cruz Eng H: Writing - Original Draft Preparation, Writing - Review \& Editing

Competing interests: No competing interests were disclosed.

Grant information: The author(s) declared that no grants were involved in supporting this work.

Copyright: ( 2020 Elvir-Lazo OL et al. This is an open access article distributed under the terms of the Creative Commons Attribution License, which permits unrestricted use, distribution, and reproduction in any medium, provided the original work is properly cited.

How to cite this article: Elvir-Lazo OL, White PF, Yumul R and Cruz Eng H. Management strategies for the treatment and prevention of postoperative/postdischarge nausea and vomiting: an updated review [version 1; peer review: 2 approved] F1000Research 2020, 9(Faculty Rev):983 https://doi.org/10.12688/f1000research.21832.1

First published: 13 Aug 2020, 9(Faculty Rev):983 https://doi.org/10.12688/f1000research.21832.1 


\section{Introduction}

Nausea is an unpleasant sensation causing discomfort in the stomach area which gives the feeling of the impending need to vomit or retch. It is often a transient sensation which is frequently followed by active retching or tachycardia and increased salivation ${ }^{1,2}$. Vomiting is the involuntary, forceful expulsion of the contents of the stomach through the mouth and/or nose ${ }^{3,4}$. The incidence of these side effects varies from $30-80 \%$ after elective surgery depending on the type of anesthesia and surgery as well as predisposing patient risk factors $^{5,6}$.

Postoperative nausea and vomiting (PONV) describes nausea and/or vomiting or retching occurring in the postanesthesia care unit (PACU) or during the first 24-48 hours after surgery ${ }^{7}$. Postdischarge nausea and vomiting (PDNV) refers to symptoms that occur after discharge from the hospital or surgical care facility $^{8}$. Not only is PONV a distressing complication from the patient's perspective but also it can result in dehydration, electrolyte imbalance, acid base imbalance, pulmonary aspiration, pneumothorax, hypoxia, esophageal rupture, increased intracranial pressure, suture rupture, wound dehiscence, bleeding, delay in the ability to resume oral intake, prolonged PACU and/or hospital stay, fatigue, anxiety, unanticipated hospital admission or readmission, and increased medical costs. The distressing symptoms of PONV/PDNV also contribute to patient dissatisfaction with their surgical experience ${ }^{9-12}$. PONV prophylaxis is economically beneficial for the hospital when a rational multimodal program is implemented based on patient and procedural risk factors ${ }^{13,14}$.

There have been over 4,000 peer-reviewed publications describing treatments for PONV/PDNV in the last 50 years, and numerous new antiemetic drugs and devices have been introduced into clinical practice, yet practitioners have been unable to eliminate this common postoperative problem ${ }^{6,15}$. The use of opioid analgesics during the perioperative period for the treatment and/or prevention of pain is a major contributing factor in patients who are at risk of developing PONV and
PDNV. Dinges et al. ${ }^{16}$ found that, compared to morphine, the risk ratio for nausea and vomiting did not significantly differ among different opioid compounds except for a higher incidence with buprenorphine and a lower incidence with fentanyl. Despite more widespread use of combinations of prophylactic antiemetic drugs, shorter-acting anesthetic, analgesic, and muscle relaxant drugs, and multimodal analgesic regimens, PONV still affects approximately $30 \%$ of all elective surgical patients, with certain high-risk patients experiencing rates of up to $80 \% \%^{5,6,17}$. As newer antiemetic drugs with better safety profiles are introduced into clinical practice, clinical studies are needed to determine the most cost-effective practices for controlling PONV while minimizing other side effects due to unexpected drug-drug interactions. The high incidence of PONV has persisted in part because of the tremendous growth in ambulatory surgery and the increased emphasis on earlier mobilization and discharge after both minor and major operations ${ }^{18}$. One in four patients undergoing ambulatory laparoscopic surgery experienced PONV before discharge. Also, the combination of PONV and pain was present in more than $50 \%$ of this patient population. Of interest, a higher incidence of PONV was reported in patients with longer preoperative waiting times $(>45 \text { minutes })^{19}$. Despite the extensive literature, the optimal prophylactic antiemetic regimen for specific surgical procedures has not been established ${ }^{5,17,20}$. This review article will focus on the most recently published peer-reviewed literature, as well as some of the classical references, considering both prevention and treatment of PONV using evidencebased multimodal antiemetic prophylaxis regimens. We will also examine pharmacological and nonpharmacological approaches.

\section{Risk factors for PONV and PDNV}

By identifying risk factors for PONV, we can ensure that those patients who are the most in need and stand to gain the greatest benefit receive optimal antiemetic prophylaxis ${ }^{21-26}$. A number of factors, including patient-, anesthetic-, and surgical-related factors, influence the occurence of postoperative emetic symptoms (Table 1-Table 3) ${ }^{27,28}$. Patient-specific factors include female gender (odds ratio [OR] 2.57), non-smoking

Table 1. Postoperative nausea and vomiting (PONV) risk factors in adults related to patient, anesthesia, and surgery.

\begin{tabular}{|l|l|}
\hline Category & Risk factors in adults \\
\hline Patient related & $\begin{array}{l}\text { Female gender } \\
\text { History of PONV } \\
\text { Motion sickness } \\
\text { Non-smoking status } \\
\text { Age }<50 \text { years }\end{array}$ \\
\hline $\begin{array}{l}\text { Anesthesia } \\
\text { related }\end{array}$ & $\begin{array}{l}\text { Anesthesia technique (general anesthesia results in higher incidence of PONV than does regional anesthesia) } \\
\text { Prolonged duration of anesthesia } \\
\text { Volatile agents } \\
\text { Nitrous oxide (>50\%) } \\
\text { Intraoperative and postoperative opioid analgesics } \\
\text { Increased doses of neostigmine (>3 mg) }\end{array}$ \\
\hline Surgery related & $\begin{array}{l}\text { Extended surgical procedures } \\
\text { Surgery categories (e.g. neurosurgery, laparoscopic surgery, cholecystectomy, intra-abdominal surgery, and } \\
\text { gynecological surgery) }\end{array}$ \\
\hline
\end{tabular}




\section{Table 2. Patient-, anesthesia-, and surgery-related risk factors for postoperative nausea and vomiting (PONV) in} children.

\section{Category $\quad$ Risk in children (Eberhart classification) ${ }^{29}$ \\ Patient related History of postoperative vomiting (POV) or PONV in relatives \\ Age $>3$ years: it is rare in children $<3$ years old, increases with age over 3 , and decreases again with puberty ${ }^{29}$ \\ Surgery related Type of surgery: strabismus ${ }^{30}$ \\ Duration of surgery $>30$ minutes \\ The risk of POV for children with 0 to 1, 2, 3, or 4 of these risk factors is associated with an incidence of PONV of 10, 30, 50, and 70\%, respectively. This scoring system has also been validated for children having surgery other than strabismus surgery; POV was observed in 3, 11, 30, and 40\% of children who had 0, 1, 2 or 3 risk factors, respectively ${ }^{31}$.}

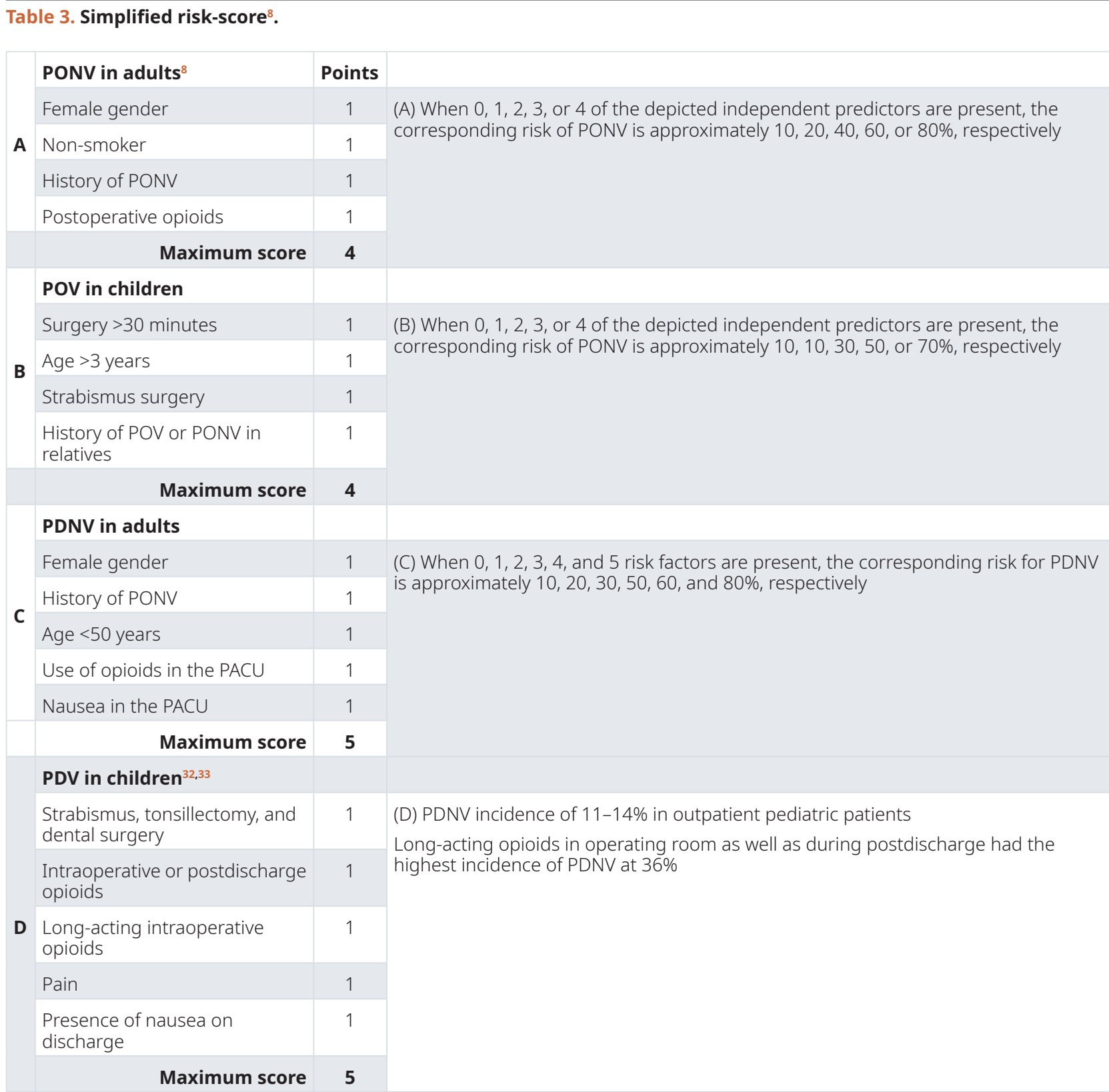

PACU, postanesthesia care unit; PDNV, postdischarge nausea and vomiting; PDV, postdischarge vomiting; PONV, postoperative nausea and vomiting; POV, postoperative vomiting 
status (OR 1.82), history of PONV or motion sickness (OR $2.09)^{34-37}$, and age $<50$ years (OR 1.79 in PACU and OR 2.17 for PDNV $)^{27,37,38}$. In children, prior to puberty, female gender does not increase the risk of $\mathrm{PONV}^{29,30,39}$. There is very limited literature regarding the risk of POV/PONV in children exposed to secondhand smoke. In children, both a prior history of PONV or postoperative vomiting (POV) and a history of PONV or POV in a parent or sibling increase their risk of POV/PONV ${ }^{31}$. Chandrakantan et al. and Kocaturk et al..$^{40,41}$ found that when PONV persisted into the postdischarge period, pain was often a contributing factor. Turgut et al..$^{42}$ also reported that PONV was more common in disabled patients younger than 18 years. Younger children were at lower risk of PONV ${ }^{29,43-45}$, while others have found no effect of age on PONV in children ${ }^{46}$.

Anesthesia-related risk factors (Table 1-Table 3) include the use of opioids, volatile agents, nitrous oxide (which increases the risk for postoperative vomiting), and high doses of neostigmine for the reversal of residual neuromuscular blockade ${ }^{32,38,47-51}$. General anesthesia is associated with a higher incidence of PONV compared with regional anesthesia ${ }^{35,52,53}$ secondary to the greater requirement for opioid medication to control postoperative pain after general anesthesia in both adults and children $^{35,54}$. The performance of peripheral nerve blocks ${ }^{55-58}$, ganglion block ${ }^{59}$, and wound infiltration with local anesthetic ${ }^{60}$ has been shown to decrease the incidence of PONV. Surgeryrelated predictors include prolonged surgical procedures, with each 30 minutes increasing the risk of PONV by $60 \%{ }^{36}$. Certain types of surgery (e.g. ophthalmic, oral, and maxillofacial surgeries, ENT surgery, neurosurgery, laparoscopy, abdominal surgeries, cholecystectomy, and gynecological surgery) have a higher incidence of PONV perhaps because of the longer exposure to general anesthesia and use of larger doses of opioid medications. In open abdominal or intra-abdominal laparoscopic surgery, post-operative ileus can occur because of gut ischemia releasing $5-\mathrm{HT}^{8,38}$. Opioid use is related to a number of perioperative side effects, one of which is PONV, and they can hinder hospital discharge and return to normal activities of daily life after surgery ${ }^{61,62}$. Li et al. demonstrated that non-smoking female patients who exhibited a fentanyl-induced cough at anesthesia induction also had a higher likelihood of developing $\mathrm{PONV}^{63}$. In a retrospective observational study, Hozumi and colleagues found a dose-dependent relationship between the dosage of remifentanil administered during surgery and an increased risk of developing $\mathrm{PONV}^{64}$. Strategies to minimize the use of opioids should be considered for all patients at moderate and high risk of developing PONV. Although the notion is still controversial, some studies have suggested that the risk of PONV is higher with some opioids (e.g. morphine) than others (e.g. hydromorphone) ${ }^{65}$. Palumbo et al. ${ }^{66}$ found that compared to remifentanil, fentanyl was associated with a higher incidence of PONV after inguinal hernia repair. Tao et al. ${ }^{67}$ reported that the incidence of PONV in gynecological patients who underwent laparoscopic surgery was lower when using intraoperative and postoperative intravenous (IV) oxycodone compared to IV sufentanil. However, Han et al. ${ }^{68}$ did not find a difference in the incidence of PONV when IV oxycodone was compared to IV sufentanil in the PACU, but on the post-surgical wards a higher incidence of PONV was found in patients receiving sufentanil ${ }^{69}$. The use of long-acting opioid analgesic techniques like intrathecal morphine or modified-release oral opioids not only prolongs the duration of analgesia but also can extend the duration of $\mathrm{PONV}^{70-72}$. In one study, naloxone was added to intrathecal morphine and significantly decreased the severity of postoperative nausea and pruritus after cesarean section $^{73}$.

The use of propofol for anesthesia (or sedation) is associated with a 3.5-fold reduction in the incidence of PONV in adults and 5.7-fold reduction in children ${ }^{74}$. Bhakta et al. $^{75}$ suggested that propofol-based anesthesia (e.g. total IV anesthesia [TIVA]) was associated with significantly less POV and faster recovery compared to standard "balanced" anesthesia in patients undergoing gynecological laparoscopy. Etomidate has been shown to produce an increase of PONV compared to propofol in elderly patients undergoing gastroscopy and ambulatory surgery ${ }^{76-80}$. Ketamine has morphine-sparing effects in lower subanesthetic dosages ${ }^{81}$; however, its psychosomatic effects with high dosages during dissociative anesthesia (and sedation) have led to emergence agitation and $\mathrm{PONV}^{82}$. Pan et al. ${ }^{83}$ found that ketamine $(0.5-1.0 \mathrm{mg} / \mathrm{kg}$ intra-articular or $0.01-0.15 \mathrm{mg} / \mathrm{kg}$ IV) did not increase PONV in patients undergoing knee arthroscopy. Perioperative intravenous ketamine minimally reduced the risk of PONV (high-quality evidence) ${ }^{84}$. Moro et al. $^{85}$ compared saline to ketamine $0.2-0.4 \mathrm{mg} / \mathrm{kg}$ in patients who underwent laparoscopic cholecystectomy and found that the incidence of PONV did not differ. Controversial findings have suggested that ketamine and etomidate did not increase PONV at doses commonly administered for induction of anesthesia $^{86}$ and that low-dose ketamine may actually reduce PONV by decreasing postoperative opioid requirements ${ }^{87,88}$.

A history of chemotherapy-induced nausea and vomiting (CINV) may increase the risk of PONV after surgery (OR $3.15)^{89}$. Psychological factors such as acute anxiety sensitivity (i.e. a fear of behaviors or sensations associated with the experience of anxiety $)^{90}$ should be added to PONV risk-scores, and prophylaxis should be considered when patients show evidence of high anxiety sensitivity. Odom et al. ${ }^{91}$ found that the psychometric properties of the Ambulatory Surgery Index of Nausea, Vomiting, and Retching (AS-INVR) provided a reliable and valid measure of the amount of distress and nausea and vomiting. Ethnicity and genetic polymorphisms ${ }^{92-98}$ could be useful in improving the predictability of PONV, which would help to improve both the prevention and the treatment of PONV. For example, CYP2D6 seems to be related to a higher incidence of PONV, especially in the first 24 hours after surgery. The ABCB1 transporter could reduce PONV owing to its association with the effectiveness of ondansetron in antiemetic prophylaxis. With regard to ethnicity, the incidence of PONV is known to be higher in non-Africans than in Africans undergoing the same surgical procedures with the same anesthetic drugs ${ }^{92-98}$. Interestingly, the platelet count (PLT), mean platelet volume (MPV), and MPV/PLT ratio were used to predict POV in children ${ }^{99}$. The neutrophil/lymphocyte ratio (NLR) was also used to predict PONV: when the NLR was greater than 2 in patients undergoing ambulatory maxillofacial surgery, 
they experienced a statistically higher incidence of PONV compared to an NLR of less than $2^{100}$.

\section{Risk-scoring systems for PONV and PDNV}

Antiemetics produce major side effects ranging from mild headache to severe arrhythmia due to QTc prolongation. Therefore, it is essential to calculate the risk of developing PONV and PDNV in each patient to reduce excessive use of antiemetics for prophylaxis ${ }^{101,102}$. Apfel et al. ${ }^{103}$ developed a simplified risk-scoring system for PONV in adults; the primary predictors consist of female gender, history of PONV or motion sickness, non-smoking status, and postoperative opioid use (Table 1). The PONV risk increases by 10, 21, 39, 69, and $79 \%$ when $0,1,2,3$, and 4 factors are present, respectively. The use of Apfel's risk-scoring system is more sensitive and specific compared to predicting PONV based on history of PONV or type of surgery alone $\mathrm{e}^{103,104}$.

However, the adult risk-scores are not directly applicable to children ${ }^{30}$. The Eberhart classification scoring system is commonly used for children and includes the following risk factors $^{29}$ : age $>3$ years, duration of surgery $>30$ minutes, strabismus surgery, and history of POV or a close relative with POV/PONV. The risk of POV for children undergoing strabismus surgery with 0 to $1,2,3$, or 4 of these risk factors was $10,30,50$, and $70 \%$, respectively. This scoring system has also been validated for children having surgery other than for strabismus, and POV was observed in 3, 11, 30, and $40 \%$ of children who had $0,1,2$, or 3 risk factors, respectively ${ }^{31}$. A study by White et al. ${ }^{27}$ reported that an Apfel risk-score of 3 or 4 (versus a score of 1-2) is associated with a higher incidence of emesis in the first 24 hours after surgery irrespective of administration of multiple antiemetics as prophylaxis.

The prevention of PONV should be tailored to the patient's risk-score to avoid side effects and unnecessary costs related to administering multiple antiemetic drugs irrespective of their risk $^{105-107}$. The prevention of PDNV is still a problem in the ever-increasing group of outpatients having more complicated ambulatory and office-based surgical procedures ${ }^{108,109}$. In a multi-center study, $37 \%$ of 2,170 adult ambulatory surgery patients administered general anesthesia exhibited PDNV ${ }^{110}$. Since these patients often do not have ready access to "rescue" antiemetic drug therapies after their discharge home, the use of simple nonpharmacologic antiemetic devices (e.g. acupressure) represents a low-risk and cost-effective alternative ${ }^{108,109}$. White et al. ${ }^{111}$ used the Pressure Right acupressure device in combination with antiemetic drugs to significantly reduce the incidence of vomiting from 0-72 hours after surgery with an associated improvement in patient satisfaction with their PONV management. Coloma et al. ${ }^{112}$ reported that the use of acustimulation with the ReliefBand can be used as an alternative to ondansetron for the treatment of established PONV. However, the use of ondansetron (4 mg IV) in combination with the ReliefBand device improved the overall response rate compared to acustimulation alone. Similar results were reported by White and colleagues ${ }^{113}$. Odom-Forren et al. found that pain and postdischarge opioid use seem to be factors in late PDNV ${ }^{114}$.
The main difference between risk factors for PONV and PDNV was that patients who experienced nausea in the PACU had a threefold greater risk for developing $P_{D N V}{ }^{115}$. Interestingly, non-smoking status was not an independent predictor for PDNV. When $0,1,2,3,4$, and 5 risk factors are present, the corresponding risk for PDNV is approximately 10, 20, 30, 50, 60 , and $80 \%$, respectively ${ }^{110}$.

\section{Perioperative antiemetic drugs used for the treatment and/or prevention of PONV}

The concern with widespread prescribing of anti-vomiting drugs is primarily related to the increased costs associated with this practice, especially when expensive proprietary antiemetics are prescribed. In addition, side effects and adverse drug interactions associated with the routine use of prophylactic antiemetics is another concern (e.g. extrapyramidal effects, sedation, arrhythmias, orthostatic hypotension $)^{116-118}$. The side effects related to the routine use of prophylactic antiemetic drugs (e.g. restlessness, dry mouth, drowsiness, headache, tachycardia, hypotension, and fatigue) can also prolong the length of stay in the surgical facility and the time to restart routine activities of daily living ${ }^{119-121}$.

\section{Antiemetic drug classes}

The currently available antiemetic drugs for the treatment and prevention of PONV include the 5-hydroxytryptamine (5- $\left.\mathrm{HT}_{3}\right)$ receptor antagonists, neurokinin-1 (NK-1) receptor antagonists, corticosteroids, butyrophenones, metoclopramide, phenothiazine, prochlorperazine, antihistamines, and anticholinergics (Table 4). Conventional prophylactic dosages and suggested timings for the administration of antiemetics are listed in Table 5. Apfel et al. reported that droperidol, dexamethasone, and ondansetron all carry similar antiemetic efficacy when given for prophylaxis $^{122}$.

5-HT 3 receptor antagonists. $5-\mathrm{HT}_{3}$ receptor antagonists are recommended as the first-line regimen for PONV prophylaxis. Ondansetron IV is commonly administered near the end of surgery. Multiple trials have reported that ondansetron $4 \mathrm{mg}$ IV (usually administered before the end of surgery) was effective to prevent and treat PONV, facilitating both early and late recovery and improving patient satisfaction after different types of surgery (e.g. outpatient laparoscopy ${ }^{123}$, laparoscopic surgery ${ }^{124-126}$, major surgical procedures in women ${ }^{127}$, and cesarean section ${ }^{128}$ ). When ondansetron was administered at $8 \mathrm{mg}$, a reduction in postpartum headache up to 4 days was observed; it also reduced PONV as it did with $4 \mathrm{mg}^{128}$. Koyuncu et al. ${ }^{129}$ found that ondansetron $8 \mathrm{mg}$ decreased the analgesic effect of acetaminophen $1 \mathrm{~g}$ (then $1 \mathrm{~g}$ every 6 hours for 24 hours) during the initial postoperative period after hysterectomy. Granisetron, a more selective $5-\mathrm{HT}_{3}$ antagonist, has been suggested to provide more sustained antiemesis as a prophylactic ${ }^{124}$. White et al. showed that granisetron (1 mg orally) was just as effective as ondansetron (4 mg IV) for lowering the occurrence of PONV after laparoscopic procedures ${ }^{124}$. Granisetron has been reported to be effective alone or in combination to treat PONV in patients undergoing laparoscopic surgery ${ }^{130-132}$. Ramosetron has higher 
Table 4. Receptor site affinity of available antiemetic drugs.

\begin{tabular}{|c|c|c|c|c|c|c|c|c|}
\hline Drug group & $\begin{array}{l}\text { Dopamine } \\
\text { (D2) }\end{array}$ & $\begin{array}{l}\text { Muscarinic } \\
\text { cholinergic }\end{array}$ & $\begin{array}{l}\text { Histamine } \\
\text { (H2) }\end{array}$ & $\begin{array}{l}\text { Serotonin } \\
\text { (5-HT3) }\end{array}$ & $\begin{array}{l}\text { NK-1 } \\
\text { antagonist }\end{array}$ & $\begin{array}{l}\text { CB-1 } \\
\text { modulator }\end{array}$ & $\begin{array}{l}\text { MOR } \\
\text { antagonist }\end{array}$ & $\begin{array}{l}\text { Gaba } \\
\text { mimetic }\end{array}$ \\
\hline \multicolumn{9}{|l|}{ Antiserotonin } \\
\hline Ondansetron & - & - & - & ++++ & - & - & - & - \\
\hline Granisetron & - & - & - & ++++ & - & - & - & - \\
\hline Tropisetron & - & - & - & ++++ & - & - & - & - \\
\hline Palonosetron & - & - & - & ++++ & - & - & - & - \\
\hline \multicolumn{9}{|l|}{ Phenothiazines } \\
\hline Fluphenazine & ++++ & + & ++ & - & - & - & - & - \\
\hline Chlorpromazine & ++++ & ++ & ++++ & + & - & - & - & - \\
\hline \multicolumn{9}{|l|}{ Butyrophenones } \\
\hline Droperidol & ++++ & - & + & + & - & - & - & - \\
\hline Haloperidol & ++++ & - & + & - & - & - & - & - \\
\hline Domperidone & ++++ & - & - & - & - & - & - & - \\
\hline \multicolumn{9}{|l|}{ Antihistamines } \\
\hline Diphenhydramine & + & ++ & ++++ & - & - & - & - & - \\
\hline Promethazine & ++ & ++ & ++++ & - & - & - & - & - \\
\hline \multicolumn{9}{|l|}{ Anticholinergics } \\
\hline Scopolamine & + & ++++ & + & - & - & - & - & - \\
\hline \multicolumn{9}{|l|}{ Benzamides } \\
\hline Metoclopramide & +++ & - & + & ++ & - & - & - & - \\
\hline \multicolumn{9}{|l|}{$\begin{array}{l}\text { Tricyclic } \\
\text { antidepressants }\end{array}$} \\
\hline Amitriptyline & +++ & +++ & ++++ & - & - & - & - & - \\
\hline Nortriptyline & +++ & ++ & +++ & - & - & - & - & - \\
\hline \multicolumn{9}{|l|}{ Neurokinin-1 } \\
\hline Aprepitant & - & - & - & - & ++++ & - & - & - \\
\hline Fosaprepitant & - & - & - & - & ++++ & - & - & - \\
\hline \multicolumn{9}{|l|}{ Others } \\
\hline Dronabinol & - & - & - & - & - & ++++ & - & - \\
\hline Nabilone & - & - & - & - & - & +++ & - & - \\
\hline Naloxone & - & - & - & - & - & - & ++++ & \\
\hline Lorazepam & - & - & - & - & - & - & - & +++ \\
\hline
\end{tabular}

The number of positive signs (+) indicates receptor activity.

This table was adapted with permission from White PF (ed). Ambulatory Anesthesia and Surgery. London, WB Saunders, 1997 Page $442^{133}$

affinity to the $5-\mathrm{HT}_{3}$ receptor and longer duration of antiemetic action, resulting in a similar or greater prophylactic antiemetic effect than the older $5-\mathrm{HT}_{3}$ receptor antagonists (e.g. granisetron and ondansetron) and has also been reported to provide a better prophylactic and antiemetic efficacy in patients at moderate to high risk $^{96,134-143}$.
Palonosetron is a second-generation 5- $\mathrm{HT}_{3}$ receptor antagonist with proposed higher efficacy and more prolonged duration of action when used for antiemetic prophylaxis ${ }^{144}$. Palonosetron was found to be more efficient than ondansetron or ramosetron for antiemetic prophylaxis in patients undergoing laparoscopic surgery $^{145-147}$. However, Kim et al..$^{148}$ failed to find a difference 
Table 5. Prophylactic doses and timing for the administration of antiemetic drugs.

\begin{tabular}{|c|c|c|c|c|}
\hline Drug group & Drugs & Dose & Timing & Adverse effect \\
\hline \multirow[t]{4}{*}{$\begin{array}{l}\text { Serotonin }\left(5-\mathrm{HT}_{3}\right. \\
\text { receptor) antagonists }\end{array}$} & Ondansetron & $\begin{array}{l}4-8 \text { mg intravenously } \\
\text { (IV) every } 4-8 \text { hours }\end{array}$ & \multirow[t]{4}{*}{ End of surgery } & \multirow[t]{4}{*}{$\begin{array}{l}\text { Headaches, constipation, flushing, fatigue, } \\
\text { malaise, raised liver enzymes }\end{array}$} \\
\hline & Granisetron & $1-2 \mathrm{mg}$ IV & & \\
\hline & Ramosetron & $\begin{array}{l}0.3 \mathrm{mg} \text { IV } \\
0.1 \mathrm{mg} P O\end{array}$ & & \\
\hline & Palonosetron & $0.075-0.25$ mg IV & & \\
\hline Corticosteroids & Dexamethasone & 4-10 mg IV & $\begin{array}{l}\text { After induction of } \\
\text { anesthesia }\end{array}$ & $\begin{array}{l}\text { Elevated blood glucose level, diabetes mellitus, } \\
\text { hypotension/hypertension }\end{array}$ \\
\hline Butyrophenone & Droperidol & $0.625-1.25 \mathrm{mg} \mathrm{IV}$ & $\begin{array}{l}\text { After induction of } \\
\text { anesthesia }\end{array}$ & $\begin{array}{l}\text { Psychomimetic effects, extrapyramidal } \\
\text { side effects, Parkinson's disease, sedation, } \\
\text { lightheadedness, prolonged QT interval }\end{array}$ \\
\hline \multirow{2}{*}{$\begin{array}{l}\text { Neurokinin } \\
\text { antagonists (NK-1 } \\
\text { receptors) }\end{array}$} & Aprepitant & 40 mg orally & $\begin{array}{l}1-2 \text { hours prior to } \\
\text { induction }\end{array}$ & \multirow[t]{2}{*}{ Headaches, constipation, fatigue } \\
\hline & Fosaprepitant & 150 mg IV & $\begin{array}{l}\text { After induction of } \\
\text { anesthesia }\end{array}$ & \\
\hline Anticholinergics & Scopolamine & $\begin{array}{l}\text { Transdermal patch } \\
0.3-0.6 \text { every } 24 \\
\text { hours }\end{array}$ & $\begin{array}{l}\text { Evening prior } \\
\text { to surgery or in } \\
\text { preoperative period }\end{array}$ & $\begin{array}{l}\text { Dizziness, dry mouth, visual disturbances, } \\
\text { tachycardia, confusion, urinary retention }\end{array}$ \\
\hline \multirow[t]{2}{*}{$\begin{array}{l}\text { Dopamine } \\
\text { antagonists }\end{array}$} & Metoclopramide & $10-25$ mg IV & $\begin{array}{l}15-30 \text { minutes } \\
\text { prior to end of } \\
\text { surgery }\end{array}$ & \multirow[t]{2}{*}{$\begin{array}{l}\text { Sedation, hypotension (fast injection), } \\
\text { headache, extrapyramidal symptoms }\end{array}$} \\
\hline & Amisulpride IV & 5-10 mg IV & $\begin{array}{l}\text { At induction of } \\
\text { anesthesia }\end{array}$ & \\
\hline
\end{tabular}

between palonosetron and ramosetron in patients undergoing any type of elective surgery involving general or regional anesthesia.

Glucocorticoid steroids. Dexamethasone, a corticosteroid, has been shown to be an effective antiemetic when administered at a dosage of 4-12 mg IV ${ }^{149-151}$. However, Ormel et al. ${ }^{152}$ found that dexamethasone $4-5 \mathrm{mg}$ was equally as effective as $8-10 \mathrm{mg}$ in terms of antiemetic efficacy. Dexamethasone antiemetic efficacy alone or in combination has been reported in patients undergoing laparoscopic cholecystectomy ${ }^{153-164}$, other abdominal laparoscopic procedures ${ }^{150}$, breast cancer surgery ${ }^{165}$, large and small bowel surgery ${ }^{166}$, total knee arthroplasty ${ }^{167}$, joint replacement surgery ${ }^{168}$, gynecological laparoscopic procedures ${ }^{169,170}$, cesarean delivery ${ }^{171}$, scoliosis correction surgery ${ }^{172}$, vitrectomy under local anesthesia ${ }^{173}$, and upper extremity surgery ${ }^{174}$ as well as in endoscopic adenoidectomy ${ }^{175}$ and strabismus correction surgery ${ }^{176}$ in children. Interestingly, there are reports that dexamethasone did not reduce PONV in patients undergoing surgery for facial fracture ${ }^{177}$, laparoscopic surgery for suspected appendicitis $^{178}$, and microvascular decompression surgery of the trigeminal nerve $\operatorname{root}^{179}$. Singh et al. ${ }^{180}$ concluded that dexamethasone has equal antiemetic efficacy compared to $5-\mathrm{HT}_{3}$ receptor antagonists up to 24 hours after surgery. Concerns remain regarding potential complications (e.g. delayed wound healing, hyperglycemia, and risk of infections) in "at-risk" patient populations (e.g. diabetics) ${ }^{122,181}$.
Betamethasone has also been shown to be an effective antiemetic. Aasboe et al. ${ }^{182}$ compared betamethasone $12 \mathrm{mg}$ intramuscularly (IM) to saline when administered 30 minutes before the start of surgery and reported that betamethasone reduced both postoperative pain and nausea in outpatients undergoing ambulatory foot (hallux valgus) surgery or hemorrhoid procedures. Comparable results were attained in patients undergoing ambulatory surgery ${ }^{183}$ and elective breast surgery ${ }^{184}$ and in high-risk cardiac surgical patients ${ }^{185}$. However, in a placebo-controlled study by Nordin et al. ${ }^{186}$ comparing betamethasone $8 \mathrm{mg}$ per os (PO) and betamethasone $8 \mathrm{mg}$ IV when administered 1 hour before induction of anesthesia in patients undergoing elective Roux-y-gastric bypass, betamethasone was of limited benefit in preventing PONV.

NK-1 receptor antagonists. NK-1 receptor antagonists with long elimination half-life values are effective for the prophylaxis and treatment of $\mathrm{PONV}^{187}$. Gesztesi et al. ${ }^{188}$ found that the NK-1 receptor antagonist CP-122,721 (200 mg PO) decreased emetic episodes compared with ondansetron (4 mg IV) during the first 24 hours after gynecologic surgery. The NK-1 receptor antagonist aprepitant appears to be more effective in decreasing PONV as compared with ondansetron ${ }^{189,190}$. Aprepitant alone or in combination was associated with a low overall incidence of PONV ${ }^{191,192}$ in patients undergoing laparoscopic surgery ${ }^{193}$, craniotomy ${ }^{194}$, mastectomy and thyroidectomy ${ }^{195}$, and elective 
surgery ${ }^{196}$ and in pediatric patients ${ }^{197}$. Because of its high cost, aprepitant should be used only in patients at high risk of developing PONV and in those who could experience serious adverse outcomes due to PONV as well as in patients who may have side effects from less-expensive antiemetic drugs ${ }^{191,192}$.

Fosaprepitant $150 \mathrm{mg}$ IV, a water-soluble lipid formulation of the NK-1 receptor antagonist, was compared to IV ondansetron $4 \mathrm{mg}$ when administered before induction of anesthesia in patients with a moderate-to-high risk of PONV (Apfel simplified score $\geq 2$ ) undergoing general anesthesia ${ }^{197}$, obtaining a greater decrease in the incidence of vomiting during the first 48 hours after surgery. Similar results were reported in patients undergoing craniotomy ${ }^{198}$ and gynecologic abdominal surgery with patient-controlled epidural analgesia ${ }^{199}$.

Butyrophenone. Droperidol, which acts on central dopamine receptors, is a highly cost-effective antiemetic treatment, regardless of the risk of extrapyramidal side effects and the potential for prolonging the electrocardiographic QT interval ${ }^{200}$. Multiple well-controlled, randomized, comparative clinical trials have validated droperidol to be as safe and effective as the more costly $5-\mathrm{HT}_{3}$ and $\mathrm{NK}-1$ antagonists ${ }^{201,202}$. There is minimal to no clinical significance in the degree of QT-interval prolongation correlating to antiemetic doses of the drug ${ }^{203}$. The risk of QTc prolongation was actually decreased by administrating a combination of droperidol and a $5-\mathrm{HT}_{3}$ receptor antagonist $\mathrm{t}^{204}$. The combination of dexamethasone, ondansetron, and droperidol is highly efficacious in preventing PONV in adults. Clinical studies have stated the efficacy of droperidol in reducing PONV in different surgical procedures such as tonsillectomy in children $^{205}$ and ambulatory surgery ${ }^{206}$. Nevertheless, Bourdaud et $a l .{ }^{207}$ compared the efficacy of a combination of ondansetron (100 $\mu \mathrm{g} / \mathrm{kg}, \mathrm{IV})$, dexamethasone $(125 \mu \mathrm{g} / \mathrm{kg}, \mathrm{IV})$, and droperidol $(50 \mu \mathrm{g} / \mathrm{kg}, \mathrm{IV})$ in pediatric patients at high risk of POV and concluded that adding droperidol to a prophylactic combination of ondansetron and dexamethasone did not decrease the incidence of POV below that obtained with the two drugs alone, though the addition of droperidol increased the risk of drowsiness. Singh et $a l .{ }^{208}$ reported that haloperidol was equivalent to the popular $5-\mathrm{HT}_{3}$ receptor antagonists in preventing vomiting on the first day after surgery. The incidence of QTc prolongation with haloperidol is statistically equivalent to the 5- $\mathrm{HT}_{3}$ antagonists. Brettner et al. ${ }^{209}$ found gender-specific differences in the incidence of PONV (female $>$ males) in the PACU after low-dose haloperidol (0.5 mg IV).

Dopamine antagonists and gastrokinetic drugs. Metoclopramide is one of the most utilized antiemetics for treating PONV when 5- $\mathrm{HT}_{3}$ antagonists, dexamethasone, and/or droperidol prophylaxis is unsuccessful. A systematic review reported that in patients undergoing cesarean delivery under neuraxial anesthesia, the use of metoclopramide $10 \mathrm{mg}$ IV was effective and safe for the prevention of early $\mathrm{PONV}^{210}$. Amisulpride has been found to be effective in treating PONV after failed prophylaxis ${ }^{211}$ in treating patients at low-to-moderate risk of PONV who received no prior PONV prophylaxis ${ }^{212}$, patients at moderate-to-high risk $^{213}$, or patients at high risk of PONV who developed emetic symptoms after prophylaxis with ondansetron or dexamethasone ${ }^{214}$.
Anticholinergics. Scopolamine is a centrally active anticholinergic drug and can be as efficacious as droperidol $(1.25 \mathrm{mg})$ or ondansetron $(4 \mathrm{mg})$ in reducing PONV in the early and late postoperative periods. Nonetheless, there are concerns about using it routinely for antiemetic prophylaxis because of its slow onset of action and adverse effects (e.g. dry mouth, drowsiness, and visual disturbances) ${ }^{215}$. Despite this, scopolamine remains a suitable and cost-effective substitute to ondansetron in multimodal treatment prophylaxis in patients with motion-induced emesis and high-risk patients undergoing major operation ${ }^{215}$. Apfel et al. ${ }^{216}$ reported that transdermal scopolamine (TDS) was associated with significant reductions in PONV during the first 24 hours after anesthesia. TDS was also associated with a higher prevalence of visual disturbances at 24-48 hours after surgery. Pergolizzi et al. ${ }^{217}$ concluded that TDS significantly reduces PONV/PDNV in many different types of surgical patients, and it is recommended in guidelines as a first-line or second-line prophylactic antiemetic. Kassel et al. ${ }^{218}$ concluded that scopolamine should be reconsidered as a routine agent for PONV prevention in the general surgical population but should be avoided in both pediatric and elderly surgical populations.

Drugs with opioid-sparing effects contributing to antiemetic activity. Neuromodulator drugs such as tricyclic antidepressants, gabapentin, olanzapine, mirtazapine, benzodiazepines, clonidine, and cannabinoids have been reported to be effective in preventing nausea and vomiting as a result of their opioidsparing effects ${ }^{219}$. Dexmedetomidine has demonstrated opioidsparing effects in elderly patients undergoing epiduroscopy ${ }^{220}$, in patients with a high risk of PONV following gynecological laparoscopic surgery ${ }^{221}$, and in patients undergoing other types of surgical procedures ${ }^{222}$. However, dexmedetomidine has produced side effects (e.g. bradycardia and hypotension). Gabapentin has been reported to produce anti-nauseant effects in various clinical settings owing to opioid-sparing effects ${ }^{223-228}$. However, White et al. found that preoperative pregabalin failed to decrease either PONV or postoperative pain after major gynecologic surgery ${ }^{229}$. The administration of dimenhydrinate is limited because of its adverse events profile (e.g. dizziness, sedation, and dry mouth, throat, and nose). Kizilcik et al. ${ }^{230}$ found that the dexamethasone-dimenhydrinate combination was effective for PONV prophylaxis. Mirtazapine, a 5- $\mathrm{HT}_{3}$ receptor antagonist capable of blocking adrenergic receptors, has been shown to be effective for PONV prophylaxis and to decrease nausea and vomiting in patients after a variety of surgical procedures ${ }^{231,232}$. Midazolam, a short-acting benzodiazepine, has been reported to reduce the incidence of PONV and provide an anxiolytic effect in patients undergoing cholecystectomy, appendectomy, gynecological surgery, middle ear surgery, thyroidectomy, and intragastric balloon placement ${ }^{233-241}$. Antipsychotic therapies including olanzapine, aripiprazole, and risperidone have been reported to reduce the need for antiemetic medication in the $\mathrm{PACU}^{242}$. Kang et al. ${ }^{243}$ reported that the combination of palonosetron $0.075 \mathrm{mg}$ and the muscle relaxant reversal drug sugammadex $2 \mathrm{mg} / \mathrm{kg}$ reduced the incidence of PONV in patients undergoing microvascular decompression. Acetaminophen preoperatively has been associated with a reduced incidence of PONV in children undergoing strabismus surgery ${ }^{244}$. However, Roberts et $a l .{ }^{245}$ found that children who received IV 
acetaminophen were more likely to experience PONV. Nabilone, a synthetic cannabinoid, has proven clinical utility in chemotherapy-related nausea and vomiting and PONV. However, oral nabilone $0.5 \mathrm{mg}$ (versus placebo) in patients with preoperative risk of PONV greater than $60 \%{ }^{246}$ was reported to be ineffective when given prior to surgery. The addition of nalbuphine $(0.5 \mathrm{mg})$ reduced the incidence and severity of PONV and pruritus after cesarean delivery ${ }^{247}$. Perioperative intravenous lidocaine infusion (1-5 mg/kg/hour or $2-4 \mathrm{mg} / \mathrm{kg} / \mathrm{hour}$ ) has been reported to reduce PONV, pain scores, perioperative opioid consumption, and duration of hospital stay and accelerate the restoration of bowel function ${ }^{248-257}$. However, Dewinter et al. ${ }^{258}$ failed to confirm these findings, concluding that systemic lidocaine had no analgesic effect when added to an opioid-based anesthetic regimen for arthrodesis procedures. Clonidine is an alpha 2 adrenergic agonist which has been used both orally and via neuraxial administration as an adjuvant for the treatment of pain and PONV in a wide variety of surgical procedures (e.g. breast, thyroid, and lower abdominal surgery and laparoscopic cholecystectomy in adults and strabismus surgery in children). Clonidine has been shown to improve pain, reduce morphine consumption, decrease PONV, reduce postoperative shivering, and improve hemodynamic and sympathetic stability ${ }^{259-264}$. However, there are also published studies which have contradicted these findings $\mathrm{s}^{72,265-268}$. Some also reported higher Ramsay sedation scores with clonidine ${ }^{266}$.

Adequate IV fluid hydration is an effective strategy for decreasing the baseline risk for PONV. It has been suggested that early rehydration in surgical patients with prolonged fasting decreases $\mathrm{PONV}^{269}$. Studies have reported that the administration of perioperative IV colloid ${ }^{270}$, perioperative IV crystalloid $^{271,272}$, and Ringer's lactate $(30 \mathrm{~mL} / \mathrm{kg} / \text { hour })^{273}$ and early postoperative oral fluid intake ${ }^{274}$ were associated with a lower incidence of PONV. It has also been suggested that the administration of a perioperative infusion of dextrose reduces PONV $^{275}$. Nevertheless, two meta-analyses ${ }^{276,277}$ reported that perioperative IV dextrose did not reduce the risk for PONV but was effective in reducing the need for antiemetic rescue medications after general anesthesia.

Ginger root is an herbal compound which contains gingerol (Ginjervel) and shogaol (Chagall), which reduce stomach contractions and increase the activity of the gastrointestinal tract and motility due to anticholinergic and antiserotonergic actions, increasing gastric emptying ${ }^{278-280}$. Ginger possesses antiserotonergic activity and has free radical scavenging effects on free radicals that induce vomiting ${ }^{281,282}$. Ginger is safe and well tolerated, which appears to be useful in both pregnancy ${ }^{283-285}$ and chemotherapy-induced $\mathrm{PONV}^{286}$, reducing the need for antiemetic rescue medications ${ }^{287-297}$. Ginger has also reduced PONV in patients undergoing cholecystectomy ${ }^{287-289}$, nephrectomy ${ }^{282,291}$, gynecologic/obstetric surgery ${ }^{293-295}$, ambulatory surgery $^{292}$, cataract surgery ${ }^{298}$, and thyroidectomy ${ }^{299}$. However, there are also several studies that have reported contradictory results $^{300-302}$. Alcohol pads containing isopropyl alcohol, when applied under the nose, are a highly cost-effective treatment for transient PONV in adults and children ${ }^{303-307}$.
Aromatherapy such as essential oils (i.e. spearmint, peppermint, ginger, lavender, and blended orange and peppermint) has also been demonstrated to provide benefits in reducing PONV and PDNV when added to a standard antiemetic treatment regimen ${ }^{296,308-313}$. However, there are other authors who have not found any evidence that aromatherapy decreases PONV ${ }^{314-318}$.

\section{Nonpharmacologic therapies for PONV and PDNV}

A wide variety of nonpharmacologic techniques have been used to control emetic symptoms in the postoperative period alone or in combination, including acupressure ${ }^{319,320}$, acupuncture a $^{321,322}$, and transcutaneous electrical nerve stimulation (TENS) ${ }^{113,323-325}$. TENS combined with a wristband pressing on Neiguan P-6 acupoint was effective in preventing PONV after laparoscopic cholecystectomy $^{326}$. White et al. reported that TENS and ondansetron was effective in PONV prophylaxis ${ }^{113}$. These results were later confirmed when acustimulation was shown to possess analgesic effects ${ }^{327}$. The adjunct use of the Pressure Right acupressure device was shown to improve the emetic potency of commonly used drugs for antiemetic prophylaxis (e.g. ondansetron, droperidol, and dexamethasone) after major laparoscopic surgery ${ }^{115}$. Lee et al. described the use of P-6 acupoint stimulation for PONV as superior to non-acupoint or sham treatments in reducing PONV and need for rescue antiemetic treatment in the postoperative period ${ }^{328}$. Acupuncture at ear acupoint alone or in combination with stimulation at the wrist (P-6 acupoint) has been found to be an effective treatment to reduce PONV ${ }^{329-331}$. Similar results with dry cupping at the P-6 acupoint $^{332}$ and preoperative electro-acupuncture ${ }^{333}$ were found. The Society for Ambulatory Anesthesia guidelines ${ }^{38}$ mentioned that stimulation of the P-6 acupoint is an effective complementary method to reduce PONV. Other studies support the beneficial effect of P-6 acupoint stimulation in reducing PONV and the need for rescue antiemetics ${ }^{12,334-337}$. Acupoints such as Laogong (PC8), Waiguan (SJ5), Zusanli (ST36), Hegu (LI4), and Quchi (LI11) can be used for reducing PONV as well ${ }^{338-349}$. In the pediatric population, acupuncture, electroacupuncture, and laser acupuncture at the P-6 acupoint have all been used to prevent POV after tonsillectomy and/or adenoidectomy, hernia repair, circumcision, orchidopexy, chemotherapy, and strabismus procedures ${ }^{321,350-362}$. However, there are other studies that used these modalities in both adults and children with negative results ${ }^{363-366}$. Chewing gum was also associated with a lower incidence of postoperative ileus and PONV ${ }^{367-370}$; however, Ge et al..$^{371}$ found no difference.

Music therapy has been alleged to decrease patient anxiety, pain, and emesis, hospital length of stay, and fatigue after surgeries such as hernia repair, coronary angiography, valve replacement, cardiac surgery, breast surgery, elective cesarean section, sigmoidoscopy, colonoscopy, knee arthroplasty, hand surgery, cystoscopy, hysterectomy, gynecological surgery, varicose vein surgery, general abdominal surgery, laparoscopic cholecystectomy, and urological procedures ${ }^{336,372-389}$. However, other studies showed that music therapy did not significantly reduce PONV $^{390,391}$. Other alternative modalities such as foot massage were reported to decrease pain and incidence of nausea and improve blood circulation in patients who underwent 
laparoscopic cholecystectomy ${ }^{392}$. Frozen ice pops reduced PONV in patients at high risk of PONV who were undergoing major joint replacement surgery ${ }^{393}$. Another important therapeutic goal for PONV prophylaxis is to avoid surgical oxygen desaturation and maintain muscular tissue oxygen saturation at $>70 \%$ of the baseline values ${ }^{394}$ and a normal cerebral oxygen saturation ${ }^{395}$. These nonpharmacologic alternative therapies can produce additive effects to standard antiemetic drugs without increasing side effects or producing adverse drug interactions.

\section{Preventing PONV and PDNV through multimodal prophylaxis}

PONV has multiple factors contributing to its etiology, leading to an increased awareness in the use of combined therapies that incorporate more than two strategies depending on the overall risk for any given patient ${ }^{396}$. Multimodal interventions not only reduce PONV but also, more importantly, enhance patient comfort after surgery ${ }^{58}$. There is no evidence to date to suggest that any one specific antiemetic therapy is especially effective for a particular patient profile or operation. Therefore, a combination of antiemetic drug therapies that act at different neuroreceptor sites has been recommended for at-risk patients ${ }^{397}$. Some clinicians used a simple method involving the administration of one antiemetic medication for each of the Apfel PONV risk factors. It is commonly accepted that increasing the number of administered antiemetics from one to three improves PONV prophylactic benefit for higher risk patients ${ }^{122}$. Clinical research has shown combining prophylactic antiemetic drugs can lower the rate of PONV and PDNV occurrence as well as improve the patient's satisfaction with and assist in their recovery in comparison to using a single antiemetic drug ${ }^{9,398}$. Implementation of PONV guidelines and the assessment of the risk of PONV using the Apfel scoring system reduced the incidence of PONV in patients undergoing ambulatory breast surgery and improved anesthesia providers' compliance with a preoperative PONV risk assessment ${ }^{61,399-402}$. A combination therapy with antiemetic drugs acting at separate receptor sites should be provided to patients with moderate-to-high risk for $\mathrm{PONV}^{396}$. A multimodal approach provides a considerable decrease in the incidence of PONV to less than $10 \%$ along with an increase in patient satisfaction and reduced side effects ${ }^{203,403}$.

Bruderer et al. ${ }^{404}$ proposed a standardized PONV prophylaxis for ambulatory surgery based on patients' Apfel risk-score (0-4): ondansetron (Apfel risk-score 2), additional dexamethasone (Apfel risk-score 3), and additional droperidol (Apfel riskscore 4). These investigators achieved low rates of PONV in $\sim 90 \%$ of their patients, and PDNV was not a problem on the first day after surgery. In fact, pain after discharge was a much more common problem. Bergese et al. ${ }^{405}$ found that triple therapy with scopolamine, ondansetron, and dexamethasone was an effective regime to prevent PONV in moderate- to high-risk patients undergoing craniotomy procedures. Dexamethasone and a $5-\mathrm{HT}_{3}$ receptor antagonist combination has superior efficacy and thus it is recommended as the "ideal" choice for routine PONV prophylaxis ${ }^{406}$. However, a study including same-day surgery patients with varying PONV risk factors revealed that adding ondansetron to a combination of low-dose droperidol and dexamethasone failed to increase antiemetic efficacy ${ }^{407,408}$.
No difference was observed when comparing efficacy among combinations of $5-\mathrm{HT}_{3}$ receptor antagonist with dexamethasone, $5-\mathrm{HT}_{3}$ receptor antagonist with droperidol, or dexamethasone with droperidol ${ }^{409}$. Interestingly, there was no reduction in PONV in the combinations containing metoclopramide compared to monotherapy alone $\mathrm{e}^{410}$.

As most patients undergoing surgery have one or two risk factors and $20-40 \%$ of these patients are expected to suffer from PONV if they do not receive a prophylactic antiemetic drug, combination antiemetic therapies have become increasingly vital in preventing PONV. Ideally, prophylaxis for PDNV would continue much further than the point of discharge from hospital or free-standing surgical care facility ${ }^{108,109}$. Recent research focused on different antiemetic drugs administered at various time points after surgery has evaluated the effects on reducing PDNV. For example, a study demonstrated that patients who received the combination of ondansetron ( $4 \mathrm{mg}$ IV) and an oral disintegrating tablet of ondansetron $(8 \mathrm{mg})$ immediately before discharge had less severe nausea and fewer vomiting episodes compared to IV ondansetron alone after discharge $(3 \% \text { versus } 23 \%)^{411}$. In a multi-center study, intraoperative dexamethasone did not appear to reduce PONV in the PACU but significantly reduced $\mathrm{PDNV}^{110}$. Dewinter et al. ${ }^{412}$ tested the effectiveness of a simplified algorithm for PONV prophylaxis with female patients receiving triple IV prophylaxis (dexamethasone and ondansetron plus either a target-controlled infusion with propofol or droperidol) and male patients received double prophylaxis with dexamethasone IV and ondansetron IV. This simplified algorithm for PONV prophylaxis resulted in a significant reduction in the incidence of PONV and better compliance with the PONV algorithm (46\% versus $18 \%$, $P=0.0001)$. Kumar et al. ${ }^{413}$ compared a single dose of palonosetron $0.075 \mathrm{mg}$ IV plus dexamethasone $4 \mathrm{mg}$ IV to ondansetron $8 \mathrm{mg}$ IV plus dexamethasone $4 \mathrm{mg}$ IV (with ondansetron $4 \mathrm{mg}$ administered every 8 hours IV for 48 hours) for PONV prophylaxis in post-chemotherapy ovarian cancer surgery patients receiving opioid-based patient-controlled analgesia (PCA). $\mathrm{Ryu}^{414}$ found that palonosetron prophylaxis reduced the incidence and severity of PONV in high-risk patients undergoing total knee arthroplasty with a multimodal analgesia protocol consisting of spinal anesthesia, a continuous femoral nerve block, and fentanyl-based IV PCA. The increasing use of inexpensive, disposable acupressure devices (e.g. Relief Band, Pressure Right) should also be considered in patients at high risk for PDNV. In addition, these patients should be given instructions for appropriate "rescue" antiemetic treatment before they are discharged home. Recommendations for optimal antiemetic dosing when utilizing a combination "multimodal" therapy consisting of dexamethasone, droperidol, and ondansetron are as follows: ondansetron $4 \mathrm{mg} \mathrm{IV,} \mathrm{4-8} \mathrm{mg}$ of IV dexamethasone, and $0.625-1.25 \mathrm{mg}$ of IV droperidol ${ }^{415}$. Another study confirmed that low-dose granisetron (0.1 mg IV) in combination with dexamethasone ( $8 \mathrm{mg}$ IV) is as effective as the combination of IV ondansetron $(4 \mathrm{mg})$ and IV dexamethasone $(8 \mathrm{mg})^{416}$. Therefore, antiemetic drugs are now commonly administered at both the start and the end of surgery to patients considered to be at high risk of developing $\mathrm{PONV}^{417}$. Adherence to validated PONV prophylaxis guidelines should be carefully 
evaluated before the patient is discharged from the PACU to guarantee that patients have received appropriate PONV prophylaxis during the perioperative period ${ }^{418}$.

\section{Combined treatments for managing established PONV}

Swift antiemetic management is mandated whenever PONV happens in patients who either did not obtain adequate prophylaxis or had ineffective prophylaxis. If PONV occurs in the immediate postoperative phase (within 6 hours postoperatively), despite antiemetic prophylaxis, an antiemetic belonging to a pharmacologic class other than that of the prophylactic drug regimen should be given. However, if the PONV occurs over 6 hours after surgery, it is suggested that a repeat dose of the original prophylactic is administered. If no prophylaxis was given, the recommended treatment is low-dose $5-\mathrm{HT}_{3}$ antagonist (e.g. ondansetron 1-2 mg IV). Alternative treatments for active PONV include intravenous metoclopramide $(10 \mathrm{mg})$, droperidol $(0.625 \mathrm{mg})$, promethazine $(6.25-12.5 \mathrm{mg})$, dolasetron (12.5 mg), granisetron (0.1 $\mathrm{mg})$, palonosetron $(0.075 \mathrm{mg})$, or tropisetron $(0.5 \mathrm{mg})^{419,420}$. Algorithms describing how to identify high-risk patients and how to guide the administration of multimodal treatments can significantly reduce the incidence of PONV and PDNV ${ }^{40,421-423}$. Yazbeck-Karam et al. ${ }^{424}$ investigated haloperidol versus ondansetron for the treatment of established PONV following general anesthesia and found that haloperidol (1 mg IV) was not inferior to ondansetron (4 mg IV) in the early treatment of established PONV. However, haloperidol was associated with an increased level of sedation ${ }^{423}$. Hu et al. ${ }^{425}$ combined a low dose of $2.5 \mu \mathrm{g} / \mathrm{kg}$ palonosetron with $15 \mu \mathrm{g} / \mathrm{kg}$ of droperidol and achieved a similar prophylactic effect as a higher $7.5 \mu \mathrm{g} / \mathrm{kg}$ dose of palonosetron compared to $7.5 \mu \mathrm{g} / \mathrm{kg}$ alone for treating emesis after eye surgery. For the treatment of existing PONV prior to discharge, a multimodal strategy should be considered because the recurrence rate of PONV over the subsequent 24 hours is $35-50 \%{ }^{426}$. A combination of low-dose ondansetron plus dexamethasone and droperidol or haloperidol has been found to be superior to monotherapy alone for the treatment of PONV in the $\mathrm{PACU}^{427}$. Those interventions have proven to be effective for both prophylaxis for and treatment of PONV. Therneau et $a l .{ }^{428}$ found that the addition of aprepitant $40 \mathrm{mg}$ PO to a multimodal antiemetic prophylactic regimen (triple antiemetic prophylaxis with dexamethasone, droperidol, and ondansetron) was associated with significant reduction of PONV during both the early recovery period and the first 48 hours postoperatively in patients undergoing bariatric surgery. Trimas and Trimas ${ }^{429}$ concluded that a single dose of aprepitant $40 \mathrm{mg}$ PO administered preoperatively can decrease the incidence of PONV in the early postoperative period after facial plastic surgery compared with ondansetron alone.

\section{Summary of current recommendations for reducing the risk of PONV and PDNV}

The management strategy for each individual patient should be based on the level of risk for PONV, the patient's pre-existing condition, patient preference, and cost efficiency. Patients should be informed about the potential consequences of PONV and PDNV during the preoperative evaluation. In addition to using a combination of antiemetic drugs with different mechanisms of action, the multifactorial etiology of PONV would also be best addressed by adopting a multimodal approach to pain management and minimizing baseline risk factors associated with PONV and PDNV in high-risk patients (Table 3). Several effective strategies are recommended for reducing the baseline risk for PONV (Table 6): (1) routine use of local anesthesia and regional anesthesia (e.g. local infiltration and/or peripheral nerve blocks); (2) propofol induction and maintenance infusion during general anesthesia and monitored anesthesia care (MAC); (3) minimization of perioperative opioid analgesics; (4) minimization of concentrations of volatile anesthetics; (5) minimization of the use of nitrous oxide and reversal drugs; and (6) ensuring adequate perioperative hydration ${ }^{17,38,52,412,430}$. If general anesthesia is utilized, substituting a propofol infusion for maintenance of anesthesia in place of inhaled volatile anesthetics will reduce the risk of PONV. A combination of propofol and air/oxygen had additive effects, reducing the risk of early PONV by approximately $25 \%{ }^{110}$. The non-opioid analgesic drugs (e.g. nonsteroidal anti-inflammatory drugs [NSAIDs] like ketorolac or ketoprofen, cyclooxygenase-2 inhibitors [COX-2] like celecoxib or meloxicam, and acetaminophen [oral or intravenous]) should be part of a multimodal perioperative analgesic regimen ${ }^{33,431-435}$. Pain and PONV after breast cancer surgery were more effectively reduced with a multimodal regimen utilizing non-opioid analgesics and antiemetics compared to a one- or two-component regimen ${ }^{433}$. Similar results were found when using an opioid-free TIVA technique for bariatric surgery ${ }^{436}$. Adequate preoperative and intraoperative IV fluid hydration is also an effective strategy for decreasing the baseline risk for $\mathrm{PONV}^{38,269,270}$. Nitrous oxide had little impact when used for procedures lasting less than 1 hour $^{437,438}$. Thus, nitrous oxide may be a good option for the short ambulatory procedures to facilitate a faster recovery from anesthesia. Although previous studies suggested that neostigmine produced dose-related increases in $\mathrm{PONV}^{51,439}$, a more recent study suggested that minimization of the neostigmine dosage failed to reduce the baseline risk of developing $\mathrm{PONV}^{440}$. Sugammadex rapidly reverses the neuromuscular blockade caused by steroid-based muscle relaxants; it is a feasible alternative to neostigmine, edrophonium, or pyridostigmine in "at-risk" patients administered non-depolarizing muscle relaxants intraoperatively ${ }^{441}$. Yağan et al. ${ }^{442}$ reported that reversal with sugammadex $2 \mathrm{mg} / \mathrm{kg}$ (compared to neostigmine $50 \mu \mathrm{g} / \mathrm{kg}$ plus atropine $0.2 \mathrm{mg} / \mathrm{kg}$ ) was associated with a lower incidence of PONV in the first hour after surgery and required less rescue antiemetic therapy in the first 24 hours after breast, strabismus, and middle ear surgery. Tas Tuna et al. ${ }^{443}$ confirmed these results in patients undergoing elective laparoscopic cholecystectomy surgery. PONV prophylaxis is rarely warranted in low-risk patients. However, moderate-risk patients benefit from single or even often multiple antiemetic drug interventions. Use of two antiemetic interventions is recommended for adults and children at moderate risk, and three ("triple") interventions should be administered to all high-risk patients ${ }^{38,426}$. The occurrences of PONV in patients who have received appropriate prophylactic antiemetic therapy should be treated aggressively using antiemetic drugs from a different pharmacologic class ${ }^{38,444}$. 
Table 6. Recommendations in relation to various risk factors of postoperative nausea and vomiting (PONV) following surgical procedures.

\begin{tabular}{|c|c|c|}
\hline $\begin{array}{c}\text { Mild risk } \\
\text { (none or } 1 \text { risk factor) }\end{array}$ & $\begin{array}{l}\text { Moderate risk } \\
\text { ( } 2 \text { risk factors) }\end{array}$ & $\begin{array}{c}\text { High risk } \\
\text { ( } \geq 3 \text { risk factors) }\end{array}$ \\
\hline $\begin{array}{l}\text { No prophylaxis required or } \\
\text { monotherapy with a cost- } \\
\text { effective antiemetic drug } \\
\text { if there is a risk of medical } \\
\text { sequelae from PONV }\end{array}$ & $\begin{array}{l}\text { Choose a prophylactic combination of antiemetic } \\
\text { medications } \\
\text { When general anesthesia is needed, decrease pre- } \\
\text { existing risk factors by reducing volatile anesthetic } \\
\text { usage, use of opioids for analgesia, nitrous oxide, and } \\
\text { elevated doses of reversal medications } \\
\text { Use neuraxial anesthesia, peripheral nerve blocks, and } \\
\text { infiltration of local anesthesia } \\
\text { Utilize adjuvant nonpharmacologic options (e.g. } \\
\text { acupressure and stimulation by electric acupoint) }\end{array}$ & $\begin{array}{l}\text { Start therapy with two or three prophylactic } \\
\text { medications that act on different receptors } \\
\text { Minimize pre-existing risks by using } \\
\text { opioid-reducing analgesia strategies } \\
\text { Reduce the use of opioids in the } \\
\text { perioperative period } \\
\text { Reduce volatile anesthetic usage, use of } \\
\text { opioids for analgesia, nitrous oxide, and } \\
\text { elevated doses of reversal medications } \\
\text { (e.g., naloxone, flumazenil, and } \\
\text { neostigmine) } \\
\text { Use neuraxial anesthesia, peripheral nerve } \\
\text { blocks, and infiltration of local anesthesia }\end{array}$ \\
\hline
\end{tabular}

In patients who did not receive antiemetic prophylaxis, first consider using a generic serotonin antagonist. Do not repeat drugs used for prophylaxis until 6 hours have elapsed after completion of surgery. Do not repeat the use of transdermal scopolamine. If refractory symptoms persist, carefully evaluate for other causative factors such as excessive opioid use, draining blood into the gastrointestinal tract or nasopharynx, or astrointestinal obstruction/ileus. Nonetheless, recognize that PONV/PDNV can still occur despite optimal prophylaxis in high-risk populations. Communication among the patient, anesthesiology team, surgical team, and perioperative nursing staff is essential for optimizing patient outcomes.
1. Singh P, Yoon SS, Kuo B: Nausea: A review of pathophysiology and therapeutics. Therap Adv Gastroenterol. 2016; 9(1): 98-112. PubMed Abstract | Publisher Full Text | Free Full Text

2. Balaban $C D$, Yates $B J$ : What is nausea? A historical analysis of changing views. Auton Neurosci. 2017; 202: 5-17. PubMed Abstract | Publisher Full Text | Free Full Text

3. Metz A, Hebbard G: Nausea and vomiting in adults--a diagnostic approach. Aust Fam Physician. 2007; 36(9): 688-92. PubMed Abstract

4. American Gastroenterological Association: American Gastroenterological Association medical position statement: Nausea and vomiting. Gastroenterology. 2001; 120(1): 261-3. PubMed Abstract | Publisher Full Text

5. Öbrink E, Jildenstål P, Oddby E, et al.: Post-operative nausea and vomiting: Update on predicting the probability and ways to minimize its occurrence, with focus on ambulatory surgery. Int J Surg. 2015; 15: 100-6. PubMed Abstract | Publisher Full Text

6. Veiga-Gil L, Pueyo J, López-Olaondo L: Postoperative Nausea and Vomiting: Physiopathology, Risk Factors, Prophylaxis and Treatment. Rev Esp Anestesiol Reanim. 2017; 64(4): 223-32. PubMed Abstract | Publisher Full Text

7. Pierre $S$, Whelan R: Nausea and vomiting after surgery. Continuing Education in Anaesthesia Critical Care \& Pain. 2013; 13(1): 28-32. Publisher Full Text
8. Feinleib J, Kwan LH, Yamani A, et al.: Postoperative nausea and vomiting. 2018. Reference Source

9. Glass PSA, White PF: Practice guidelines for the management of postoperative nausea and vomiting: Past, present, and future. Anesth Analg. 2007; 105(6): 1528-9.

PubMed Abstract | Publisher Full Text

10. Fero KE, Jalota L, Hornuss C: Pharmacologic management of postoperative nausea and vomiting. Expert Opin Pharmacother. 2011; 12(15): 2283-96. PubMed Abstract | Publisher Full Text

11. Kovac AL: Update on the management of postoperative nausea and vomiting. Drugs. 2013; 73(14): 1525-47. PubMed Abstract | Publisher Full Tex

12. Cao $X$, White $P F, M a H$ : An update on the management of postoperative nausea and vomiting. J Anesth. 2017; 31(4): 617-26. PubMed Abstract | Publisher Full Text

13. Apipan B, Rummasak D, Wongsirichat N: Postoperative nausea and vomiting after general anesthesia for oral and maxillofacial surgery. I Dent Anesth after general anesthesia for oral
Pain Med. 2016; 16(4): 273-281. PubMed Abstract | Publisher Full Text | Free Full Text

14. Dzwonczyk R, Weaver TE, Puente EG, et al.: Postoperative nausea and vomiting prophylaxis from an economic point of view. Am J Ther. 2012; 19(1): 11-5. PubMed Abstract | Publisher Full Text

15. Bellville JW, Bross IDJ, Howland WS: Postoperative Nausea and Vomiting. 
IV. Factors Related to Postoperative Nausea and Vomiting. Anesthesiology. 1960; 21: 186-93.

PubMed Abstract | Publisher Full Text

16. Dinges HC, Otto S, Stay DK, et al:: Side Effect Rates of Opioids in Equianalgesic Doses via Intravenous Patient-Controlled Analgesia: A Systematic Review and Network Meta-analysis. Anesth Analg. 2019; 129(4): 1153-62.

PubMed Abstract | Publisher Full Text | Faculty Opinions Recommendation

17. Phillips C, Brookes CD, Rich J, et al.: Postoperative nausea and vomiting following orthognathic surgery. Int J Oral Maxillofac Surg. 2015; 44(6): 745-51. PubMed Abstract | Publisher Full Text | Free Full Text

18. White PF, O'Hara JF, Roberson CR, et al.: The impact of current antiemetic practices on patient outcomes: A prospective study on high-risk patients. Anesth Analg. 2008; 107(2): 452-8.

PubMed Abstract | Publisher Full Text

19. L López-Torres López J, Piedracoba Cadahía D, Alcántara Noalles MJ, et al.: Perioperative Factors That Contribute to Postoperative Pain and/or Nausea and Vomiting in Ambulatory Laparoscopic Surgery. Rev Esp Anestesiol Reanim. 2019; 66(4): 189-98.

PubMed Abstract | Publisher Full Text | Faculty Opinions Recommendation

20. Kappen TH: Risk-tailored prophylaxis for postoperative nausea and vomiting: Has the big little problem gotten any smaller? Br J Anaesth. 2018; 120(1): 9-13.

PubMed Abstract | Publisher Full Text

21. de Souza DS, Costa AF, Chaves GV: Predisposing factors for postoperative nausea and vomiting in gynecologic tumor patients. Support Care Cancer. 2016; 24(11): 4661-7.

PubMed Abstract | Publisher Full Text

22. Albuquerque AFM, Queiroz SIM, Germano AR, et al: Factors associated to post-operative nausea and vomiting following oral and maxillofacial surgery: A prospective study. Oral Maxillofac Surg. 2017; 21(1): 49-54. PubMed Abstract | Publisher Full Text

23. Dobbeleir M, de Coster J, Coucke W, et al: Postoperative nausea and vomiting after oral and maxillofacial surgery: A prospective study. Int J Oral Maxillofac Surg. 2018; 47(6): 721-5. PubMed Abstract | Publisher Full Text

24. Groene P, Eisenlohr J, Zeuzem C, et al.: Postoperative nausea and vomiting in bariatric surgery in comparison to non-bariatric gastric surgery. Wideochir Inne Tech Maloinwazyjne. 2019; 14(1): 90-5.

PubMed Abstract | Publisher Full Text | Free Full Text

25. Halliday TA, Sundqvist J, Hultin $M$, et al.: Post-operative nausea and vomiting in bariatric surgery patients: An observational study. Acta Anaesthesio Scand. 2017; 61(5): 471-9. PubMed Abstract | Publisher Full Text

26. Son J, Yoon H: Factors Affecting Postoperative Nausea and Vomiting in Surgical Patients. J Perianesth Nurs. 2018; 33(4): 461-70. PubMed Abstract | Publisher Full Text

27. White PF, Sacan O, Nuangchamnong N, et al:: The Relationship Between Patient Risk Factors and Early Versus Late Postoperative Emetic Symptoms. Anesth Analg. 2008; 107(2): 459-63. PubMed Abstract | Publisher Full Text

28. Watcha MF, White PF: Postoperative nausea and vomiting. Its etiology, treatment, and prevention. Anesthesiology. 1992; 77(1): 162-84. PubMed Abstract | Publisher Full Text

29. Eberhart LHJ, Geldner G, Kranke P, et al.: The Development and Validation of a Risk Score to Predict the Probability of Postoperative Vomiting in Pediatric Patients. Anesth Analg. 2004; 99(6): 1630-7. PubMed Abstract | Publisher Full Text

30. Eberhart LHJ, Morin AM, Guber D, et al.: Applicability of risk scores for postoperative nausea and vomiting in adults to paediatric patients. $\mathrm{Br} J$ Anaesth. 2004; 93(3): 386-92. PubMed Abstract | Publisher Full Text

31. Kranke P, Eberhart LH, Toker H, et al.: A Prospective Evaluation of the POVOC Score for the Prediction of Postoperative Vomiting in Children. Anesth Analg. 2007; 105(6): 1592-7.

PubMed Abstract | Publisher Full Text | Faculty Opinions Recommendation

32. Efune PN, Minhajuddin A, Szmuk P: Incidence and factors contributing to postdischarge nausea and vomiting in pediatric ambulatory surgical cases. Paediatr Anaesth. 2018; 28(3): 257-63.

PubMed Abstract | Publisher Full Text

33. A Apfel CC, Turan A, Souza K, et al.: Intravenous acetaminophen reduces postoperative nausea and vomiting: A systematic review and metaanalysis. Pain. 2013; 154(5): 677-89.

PubMed Abstract | Publisher Full Text | Faculty Opinions Recommendation

34. Palazzo M, Evans R: Logistic regression analysis of fixed patient factors for postoperative sickness: a model for risk assessment. Br J Anaesth. 1993; 70(2): 135-40.

PubMed Abstract | Publisher Full Text

35. Koivuranta $M$, Läärä $E$, Snåre $L$, et al.: A survey of postoperative nausea and vomiting. Anaesthesia. 1997; 52(5): 443-449.

Publisher Full Text

36. Sinclair DR, Chung F, Mezei G: Can Postoperative Nausea and Vomiting Be
Predicted? Anesthesiology. 1999; 91(1): 109-18.

Publisher Full Text

37. Apfel CC, Heidrich FM, Jukar-Rao S, et al.: Evidence-based analysis of risk factors for postoperative nausea and vomiting. Br J Anaesth. 2012; 109(5): 742-53. PubMed Abstract | Publisher Full Text

38. Gan TJ, Diemunsch P, Habib AS, et al.: Consensus Guidelines for the Management of Postoperative Nausea and Vomiting. Anesth Analg. 2014 118(1): 85-113.

PubMed Abstract | Publisher Full Text | Faculty Opinions Recommendation

39. Rowley MP, Brown TC: Postoperative vomiting in children. Anaesth Intensive Care. 1982; 10(4): 309-13.

PubMed Abstract | Publisher Full Text

40. Chandrakantan A, Reinsel RA, Jasiewicz R, et al:: An exploratory study of the relationship between postoperative nausea and vomiting and postdischarge nausea and vomiting in children undergoing ambulatory surgery. Paediatr Anaesth. 2019; 29(4): 353-60. PubMed Abstract | Publisher Full Text | Faculty Opinions Recommendation

41. Kocaturk O, Keles S, Omurlu IK: Risk factors for postoperative nausea and vomiting in pediatric patients undergoing ambulatory dental treatment. Niger J Clin Pract. 2018; 21(5): 597-602. PubMed Abstract | Publisher Full Text

42. Turgut $\mathrm{HC}$, Alkan M, Kip G, et al.: Is age a determinant for nausea and vomiting in disabled patients after dental treatment under sedation? Niger Clin Pract. 2017; 20(11): 1497-500. PubMed Abstract | Publisher Full Text

43. Bourdaud N, Devys JM, Bientz J, et al.: Development and validation of a risk score to predict the probability of postoperative vomiting in pediatric patients: The VPOP score. Paediatr Anaesth. 2014; 24(9): 945-52. PubMed Abstract | Publisher Full Text

44. Cohen MM, Cameron CB, Duncan PG: Pediatric anesthesia morbidity and mortality in the perioperative period. Anesth Analg. 1990; 70(2): 160-7. PubMed Abstract | Publisher Full Text

45. Schreiner MS, Nicolson SC, Martin T, et al.: Should children drink before discharge from day surgery? Anesthesiology. 1992; 76(4): 528-33. PubMed Abstract | Publisher Full Text

46. Shen $\mathrm{YD}$, Chen $\mathrm{CY}, \mathrm{Wu} \mathrm{CH}$, et al: Dexamethasone, ondansetron, and their combination and postoperative nausea and vomiting in children undergoing strabismus surgery: A meta-analysis of randomized controlled trials. Paediatr Anaesth. 2014; 24(5): 490-8. PubMed Abstract | Publisher Full Text

47. Apfel CC, Kranke P, Katz MH, et al:: Volatile anaesthetics may be the main cause of early but not delayed postoperative vomiting: A randomized controlled trial of factorial design. Br J Anaesth. 2002; 88(5): 659-68. PubMed Abstract | Publisher Full Text

48. Yoon IJ, Kang H, Baek CW, et al.: Comparison of effects of desflurane and sevoflurane on postoperative nausea, vomiting, and pain in patients receiving opioid-based intravenous patient-controlled analgesia afte thyroidectomy: Propensity score matching analysis. Medicine (Baltimore). 2017; 96(16): e6681.

PubMed Abstract | Publisher Full Text | Free Full Text

49. Firoozabadi MD, Rahmani H: Prevention of Nausea and Vomiting: Methods and Utility after Surgery in Cancer Patients? Asian Pac J Cancer Prev. 2015; 16(7): 2629-35.

PubMed Abstract | Publisher Full Text

50. Prathep S, Mahattanaporn S, Wasinwong W: Target Controlled Infusion versus Sevoflurane/Desflurane Anesthesia for Laparoscopic Cholecystectomy: Comparison Postoperative Nausea/Vomiting and Extubation Time. J Med Assoc Thai. 2015; 98(12): 1187-92. PubMed Abstract

51. Tramèr MR, Fuchs-Buder T: Omitting antagonism of neuromuscular block: Effect on postoperative nausea and vomiting and risk of residual paralysis. A systematic review. Br J Anaesth. 1999; 82(3): 379-86. PubMed Abstract | Publisher Full Text

52. Sansonnens J, Taffé $P$, Burnand B: Higher occurrence of nausea and vomiting after total hip arthroplasty using general versus spinal anesthesia: An observational study. BMC Anesthesiol. 2016; 16: 44 PubMed Abstract | Publisher Full Text | Free Full Text

53. Seki H, Furumoto K, Sato M, et al.: Effects of epidural anesthesia on postoperative nausea and vomiting in laparoscopic gynecological surgery: A randomized controlled trial. J Anesth. 2018; 32(4): 608-15. PubMed Abstract | Publisher Full Text

54. Semiz A, Akpak YK, Yılanlıoğlu NC, et al.: Prediction of intraoperative nausea and vomiting in caesarean delivery under regional anaesthesia. Int Med Res. 2017; 45(1): 332-9. PubMed Abstract | Publisher Full Text | Free Full Text

55. Rivedal DD, Nayar HS, Israel JS, et al.: Paravertebral block associated with decreased opioid use and less nausea and vomiting after reduction mammaplasty. J Surg Res. 2018; 228: 307-13. PubMed Abstract | Publisher Full Text

56. Steinhaus ME, Rosneck J, Ahmad CS, et al.: Outcomes After Peripheral Nerve Block in Hip Arthroscopy. Am J Orthop (Belle Mead NJ). 2018; 47(6). PubMed Abstract | Publisher Full Text 
57. Chiu C, Aleshi P, Esserman LJ, et al.: Improved analgesia and reduced postoperative nausea and vomiting after implementation of an enhanced recovery after surgery (ERAS) pathway for total mastectomy. $B M C$ Anesthesiol. 2018; 18(1): 41. PubMed Abstract | Publisher Full Text | Free Full Text

58. $\mathrm{Ma} \mathrm{K}, \mathrm{Wu}$ X, Chen $\mathrm{Y}$, et al.: Effect of multimodal intervention on postoperative nausea and vomiting in patients undergoing gynecological laparoscopy. J Int Med Res. 2019; 47(5): 2026-33. PubMed Abstract | Publisher Full Text | Free Full Text | Faculty Opinions Recommendation

59. Abubaker AK, Al-Qudah MA: The Role of Endoscopic Sphenopalatine Ganglion Block on Nausea and Vomiting After Sinus Surgery. Am J Rhinol Allergy. 2018; 32(5): 369-73.

PubMed Abstract | Publisher Full Text

60. Sidiropoulou $\mathrm{T}$, Buonomo $\mathrm{O}$, Fabbi $\mathrm{E}$, et al:: A prospective comparison of continuous wound infiltration with ropivacaine versus single-injection paravertebral block after modified radical mastectomy. Anesth Analg. 2008; 106(3): 997-1001, table of contents.

PubMed Abstract | Publisher Full Text

61. White PF, White LM, Monk T, et al:: Perioperative Care for the Older Outpatient Undergoing Ambulatory Surgery. Anesth Analg. 2012; 114(6): 1190-215. PubMed Abstract | Publisher Full Text

62. White PF: Pain management for the elderly in the ambulatory setting. Pain Manag. 2015: 5(4): 233-6.

PubMed Abstract | Publisher Full Text

63. Li CC, Chen SS, Huang $\mathrm{CH}$, et al.: Fentanyl-induced cough is a risk factor for postoperative nausea and vomiting. $B r$ J Anaesth. 2015: 115(3): 444-8. PubMed Abstract | Publisher Full Text

64. Hozumi J, Egi M, Sugita S, et al.: Dose of intraoperative remifentanil administration is independently associated with increase in the risk of postoperative nausea and vomiting in elective mastectomy under general anesthesia. J Clin Anesth. 2016; 34: 227-31.

PubMed Abstract | Publisher Full Text

65. Liu Y, Yang L, Tao SJ: Effects of hydromorphone and morphine intravenous analgesia on plasma motilin and postoperative nausea and vomiting in patients undergoing total hysterectomy. Eur Rev Med Pharmacol Sci. 2018. 22(17): 5697-703.

PubMed Abstract | Publisher Full Text

66. Palumbo $P$, Usai S, Amatucci $C$, et al.: Postoperative nausea and vomiting (PONV) in outpatient repair of inguinal hernia. Ann Ital Chir. 2018; 89: 75-80. PubMed Abstract

67. Tao B, Liu K, Wang D, et al.: Effect of Intravenous Oxycodone Versus Sufentanil on the Incidence of Postoperative Nausea and Vomiting in Patients Undergoing Gynecological Laparoscopic Surgery. J Clin Pharmacol. 2019; 59(8): 1144-50.

PubMed Abstract | Publisher Full Text | Faculty Opinions Recommendation

68. Han L, Su Y, Xiong $\mathrm{H}$, et al:: Oxycodone Versus Sufentanil in Adult PatientControlled Intravenous Analgesia After Abdominal Surgery: A Prospective, Randomized, Double-Blinded, Multiple-Center Clinical Trial. Medicine (Baltimore). 2018; 97(31): e11552.

PubMed Abstract | Publisher Full Text | Free Full Text

69. Watanabe T, Moriya K, Tsubokawa N, et al.: Effect of remifentanil on postoperative nausea and vomiting: A randomized pilot study. J Anesth. 2018; 32(5): 781-5.

PubMed Abstract | Publisher Full Text

70. Devys JM, Mora A, Plaud B, et al.: Intrathecal + PCA morphine improves analgesia during the first $\mathbf{2 4} \mathbf{~ h r}$ after major abdominal surgery compared to PCA alone. Can J Anesth. 2003; 50(4): 355-61.

PubMed Abstract | Publisher Full Text

71. de Pietri L, Siniscalchi A, Reggiani A, et al:: The use of intrathecal morphine for postoperative pain relief after liver resection: A comparison with epidural analgesia. Anesth Analg. 2006; 102(4): 1157-63.

PubMed Abstract | Publisher Full Text

72. Dereu D, Savoldelli GL, Mercier Y, et al.: The Impact of a Transversus Abdominis Plane Block Including Clonidine vs. Intrathecal Morphine on Nausea and Vomiting After Caesarean Section: A Randomised Controlled Trial. Eur J Anaesthesiol. 2019; 36(8): 575-82. PubMed Abstract | Publisher Full Text

73. Peivandi S, Habibi MR, Baradari AG, et al.: The Effect of Adding Low-Dose Naloxone to Intrathecal Morphine on Postoperative Pain and Morphine Related Side Effects after Cesarean Section: A Double-Blind, Randomized, Clinical Trial. Open Access Maced J Med Sci. 2019; 7(23): 3979-83.

PubMed Abstract | Publisher Full Text | Free Full Text | Faculty Opinions Recommendation

74. Sneyd JR, Carr A, Byrom WD, et al.: A meta-analysis of nausea and vomiting following maintenance of anaesthesia with propofol or inhalational agents. Eur J Anaesthesiol. 1998; 15(4): 433-45.

PubMed Abstract | Publisher Full Text

75. Bhakta $P$, Ghosh BR, Singh $U$, et al.: Incidence of postoperative nausea and vomiting following gynecological laparoscopy: A comparison of standard anesthetic technique and propofol infusion. Acta Anaesthesiol Taiwan. 2016; 54(4): 108-13.

PubMed Abstract | Publisher Full Text
76. White PF: Anesthesiology-important advances in clinical medicine: Outpatient anesthesia techniques: continuous intravenous infusion of anesthetic agents. West J Med. 1984; 140(3): 437-8. PubMed Abstract | Free Full Text

77. Meng QT, Cao C, Liu HM, et al.: Safety and efficacy of etomidate and propofol anesthesia in elderly patients undergoing gastroscopy: A double-blind randomized clinical study. Exp Ther Med. 2016; 12(3): 1515-24. PubMed Abstract | Publisher Full Text | Free Full Text

78. Avramov MN, Husain MM, White PF: The Comparative Effects of Methohexital, Propofol, and Etomidate for Electroconvulsive Therapy. Anesth Analg. 1995; 81(3): 596-602.

PubMed Abstract | Publisher Full Text

79. Gazdag G, Kocsis N, Tolna J, et al:: Etomidate versus propofol for electroconvulsive therapy in patients with schizophrenia. J ECT. 2004; 20(4): 225-9.

PubMed Abstract | Publisher Full Text

80. Gholipour Baradari A, Firouzian A, Zamani Kiasari A, et al.: Effect of Etomidate Versus Combination of Propofol-Ketamine and Thiopental-Ketamine on Hemodynamic Response to Laryngoscopy and Intubation: A Randomized Double Blind Clinical Trial. Anesth Pain Med. 2016; 6(1): e30071. PubMed Abstract | Publisher Full Text | Free Full Text

81. Nesher N, Serovian I, Marouani N, et al.: Ketamine spares morphine consumption after transthoracic lung and heart surgery without adverse hemodynamic effects. Pharmacol Res. 2008; 58(1): 38-44. PubMed Abstract | Publisher Full Text

82. Vadivelu N, Schermer E, Kodumudi V, et al.: Role of ketamine for analgesia in adults and children. J Anaesthesiol Clin Pharmacol. 2016; 32(3): 298. PubMed Abstract | Publisher Full Text | Free Full Text

83. Pan L, Shen Y, Ma T, et al.: The efficacy of ketamine supplementation on pain management for knee arthroscopy: A meta-analysis of randomized controlled trials. Medicine (Baltimore). 2019; 98(27): e16138. PubMed Abstract | Publisher Full Text | Free Full Text | Faculty Opinions Recommendation

84. Brinck E, Tiippana $E$, Heesen $M$, et al.: Perioperative intravenous ketamine for acute postoperative pain in adults. Cochrane Database Syst Rev. 2018; 12(12): CD012033. PubMed Abstract | Publisher Full Text | Free Full Text

85. Moro ET, Feitosa IMPSS, de Oliveira RG, et al.: Ketamine does not enhance the quality of recovery following laparoscopic cholecystectomy: A randomized controlled trial. Acta Anaesthesiol Scand. 2017; 61(7): 740-8. PubMed Abstract | Publisher Full Text

86. St Pierre $M$, Dunkel $M$, Rutherford $A$, et al.: Does etomidate increase postoperative nausea? A double-blind controlled comparison of etomidate in lipid emulsion with propofol for balanced anaesthesia. Eur J Anaesthesiol. 2000; 17(10): 634-41. PubMed Abstract | Publisher Full Text

87. Subramaniam K, Subramaniam B, Steinbrook RA: Ketamine as adjuvant analgesic to opioids: A quantitative and qualitative systematic review. Anesth Analg. 2004; 99(2): 482-95, table of contents. PubMed Abstract | Publisher Full Text

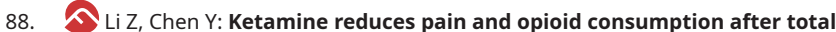
knee arthroplasty: A meta-analysis of randomized controlled studies. Int J Surg. 2019; 70: 70-83.

PubMed Abstract | Publisher Full Text | Faculty Opinions Recommendation

89. da Silva HBG, Sousa AM, Guimarães GMN, et al.: Does previous chemotherapy-induced nausea and vomiting predict postoperative nausea and vomiting? Acta Anaesthesiol Scand. 2015; 59(9): 1145-53. PubMed Abstract | Publisher Full Text

90. Laufenberg-Feldmann R, Müller M, Ferner M, et al.: Is 'Anxiety Sensitivity' Predictive of Postoperative Nausea and Vomiting?: A Prospective Observational Study. Eur J Anaesthesiol. 2019; 36(5): 369-74. PubMed Abstract | Publisher Full Text

91. Odom-Forren J, Hall LA, Fetzer SJ: Psychometric Properties of the Ambulatory Surgery Index of Nausea, Vomiting, and Retching. J Nurs Meas. 2016; 24(3): 454-64.

PubMed Abstract | Publisher Full Text

92. Alli A, Omar S, Tsang S, et al.: The effect of ethnicity on the incidence of postoperative nausea and vomiting in moderate to high risk patients undergoing general anesthesia in south africa: a controlled observational study. Middle East J Anaesthesiol. 2017; 24(2): 119-29. PubMed Abstract | Free Full Text

93. Kong Y, Yan T, Gong S, et al.: Opioid receptor mu 1 (OPRM1) A118G polymorphism (rs1799971) and postoperative nausea and vomiting. $\mathrm{Am} J$ Transl Res. 2018; 10(9): 2764-80. PubMed Abstract | Free Full Text

94. López-Morales P, Flores-Funes D, Sánchez-Migallón EG, et al:: Genetic Factors Associated with Postoperative Nausea and Vomiting: A Systematic Review. J Gastrointest Surg. 2018; 22(9): 1645-51. PubMed Abstract | Publisher Full Text

95. Klenke S, de Vries GJ, Schiefer L, et al:: CHRM3 rs 2165870 polymorphism is independently associated with postoperative nausea and vomiting, but combined prophylaxis is effective. Br J Anaesth. 2018; 121(1): 58-65. PubMed Abstract | Publisher Full Text 
96. Song JW, Shim JK, Choi SH, et al.: Comparison of Ramosetron and Palonosetron for Preventing Nausea and Vomiting after Spinal Surgery: Association With ABCB1 Polymorphisms. J Neurosurg Anesthesiol. 2017; 29(4): 406-14. PubMed Abstract | Publisher Full Text

97. Niewiński P, Wojciechowski R, Śliwiński M, et al.: CYP2D6 basic genotyping as a potential tool to improve the antiemetic efficacy of ondansetron in prophylaxis of postoperative nausea and vomiting. Adv Clin Exp Med. 2018; 27(11): 1499-503.

PubMed Abstract | Publisher Full Text

98. Candiotti KA, Birnbach DJ, Lubarsky DA, et al:: The impact of pharmacogenomics on postoperative nausea and vomiting: Do CYP2D6 allele copy number and polymorphisms affect the success or failure of ondansetron prophylaxis? Anesthesiology. 2005; 102(3): 543-9.

PubMed Abstract | Publisher Full Text

99. Canpolat D, Dogruel F, Gönen Z, et al:: The role of platelet count, mean platelet volume, and the mean platelet volume/platelet count ratio in predicting postoperative vomiting in children after deep sedation. Saudi Med J. 2016; 37(10): 1082-8. PubMed Abstract | Publisher Full Text | Free Full Text

100. Arpaci AH, Ișik B, Ilhan E, et al.: Association of Postoperative Nausea and Vomiting Incidence With Neutrophil-Lymphocyte Ratio in Ambulatory Maxillofacial Surgery. J Oral Maxillofac Surg. 2017; 75(7): 1367-71. PubMed Abstract | Publisher Full Text

101. Charbit B, Albaladejo P, Funck-Brentano C, et al.: Prolongation of QTc Interval after Postoperative Nausea and Vomiting Treatment by Droperidol or Ondansetron. Anesthesiology. 2005; 102(6): 1094-100. PubMed Abstract | Publisher Full Text

102. Krammes SK, Jacobs T, Clark JM, et al.: Effect of Intravenous Ondansetron on the QT Interval of Patients' Electrocardiograms. Pediatr Emerg Care. 2018; 34(1): 38-41.

PubMed Abstract | Publisher Full Text

103. Apfel CC, Läärä E, Koivuranta $M$, et al.: A simplified risk score for predicting postoperative nausea and vomiting: Conclusions from cross-validations between two centers. Anesthesiology. 1999; 91(3): 693-700. PubMed Abstract | Publisher Full Text

104. Apfel CC, Kranke P, Eberhart LHJ: Comparison of surgical site and patient's history with a simplified risk score for the prediction of postoperative nausea and vomiting. Anaesthesia. 2004; 59(11): 1078-82. PubMed Abstract | Publisher Full Text

105. Biedler A, Wermelt J, Kunitz O, et al.: A risk adapted approach reduces the overall institutional incidence of postoperative nausea and vomiting. Can J Anaesth. 2004; 51(1): 13-9.

PubMed Abstract | Publisher Full Text

106. Smith CA, Ruth-Sahd L: Reducing the Incidence of Postoperative Nausea and Vomiting Begins With Risk Screening: An Evaluation of the Evidence. J Perianesth Nurs. 2016; 31(2): 158-71.

PubMed Abstract | Publisher Full Text

107. Wiesmann T, Kranke P, Eberhart L: Postoperative nausea and vomiting - a narrative review of pathophysiology, pharmacotherapy and clinical management strategies. Expert Opin Pharmacother. 2015; 16(7): 1069-77. PubMed Abstract | Publisher Full Text

108. Kolodzie K, Apfel CC: Nausea and vomiting after office-based anesthesia. Curr Opin Anaesthesiol. 2009; 22(4): 532-8. PubMed Abstract | Publisher Full Text

109. Chinnappa V, Chung F: Post-discharge nausea and vomiting: An overlooked aspect of ambulatory anesthesia? Can J Anaesth. 2008; 55(9): 565-71. PubMed Abstract | Publisher Full Text

110. A Apfel CC, Philip BK, Cakmakkaya OS, et al.: Who Is at Risk for Postdischarge Nausea and Vomiting after Ambulatory Surgery? Anesthesiology. 2012; 117(3): 475-86.

PubMed Abstract | Publisher Full Text | Faculty Opinions Recommendation

111. White PF, Zhao M, Tang J, et al.: Use of a disposable acupressure device as part of a multimodal antiemetic strategy for reducing postoperative nausea and vomiting. Anesth Analg. 2012; 115(1): 31-7. PubMed Abstract | Publisher Full Text | Faculty Opinions Recommendation

112. Coloma M, White PF, Ogunnaike BO, et al: Comparison of Acustimulation and Ondansetron for the Treatment of Established Postoperative Nausea and Vomiting. Anesthesiology. 2002; 97(6): 1387-92. PubMed Abstract | Publisher Full Text

113. White PF, Issioui $T$, Hu J, et al.: Comparative efficacy of acustimulation (ReliefBand) versus ondansetron (Zofran) in combination with droperidol for preventing nausea and vomiting. Anesthesiology. 2002; 97(5): 1075-81. PubMed Abstract | Publisher Full Text

114. Odom-Forren J, Rayens MK, Gokun Y, et al.: The Relationship of Pain and Nausea in Postoperative Patients for 1 Week After Ambulatory Surgery. Clin J Pain. 2015; 31(10): 845-51. PubMed Abstract | Publisher Full Text

115. Odom-Forren J, Jalota L, Moser DK, et al.: Incidence and predictors of postdischarge nausea and vomiting in a 7-day population. J Clin Anesth. 2013; 25(7): 551-9.

PubMed Abstract | Publisher Full Text

116. Bergese SD, Puente EG, Antor MA, et al.: A Prospective, Randomized, Double-
Blinded, Double-Dummy Pilot Study to Assess the Preemptive Effect of Triple Therapy with Aprepitant, Dexamethasone, and Promethazine versus Ondansetron, Dexamethasone and Promethazine on Reducing the Incidence of Postoperative Nausea and Vomiting Experienced by Patients Undergoing Craniotomy Under General Anesthesia. Front Med (Lausanne). 2016; 3: 29 .

PubMed Abstract | Publisher Full Text | Free Full Text

117. Imani $F$, Zafarghandi-Motlagh M: Postoperative nausea and vomiting in patients undergoing laparoscopy. J Minim Invasive Surg Sci. 2013; 2: 138-43.

118. Ryu JH, Lee JE, Lim YJ, et al.: A prospective, randomized, double-blind, and multicenter trial of prophylactic effects of ramosetronon postoperative nausea and vomiting (PONV) after craniotomy: Comparison with ondansetron. BMC Anesthesiol. 2014; 14:63.

PubMed Abstract | Publisher Full Text | Free Full Text

119. Alimian M, Imani F, Faiz SHR, et al.: Effect of oral pregabalin premedication on post-operative pain in laparoscopic gastric bypass surgery. Anesth Pain Med. 2012; 2(1): 12-6.

PubMed Abstract | Publisher Full Text | Free Full Text

120. Lee A, Chan SKC, Fan LTY: Stimulation of the wrist acupuncture point PC6 for preventing postoperative nausea and vomiting. Cochrane Database Syst Rev. 2015; 2015(11): CD003281.

PubMed Abstract | Publisher Full Text | Free Full Text

121. Manahan MA, Basdag B, Kalmar CL, et al.: Risk of severe and refractory postoperative nausea and vomiting in patients undergoing diep flap breast reconstruction. Microsurgery. 2014; 34(2): 112-21. PubMed Abstract | Publisher Full Text | Free Full Text

122. Apfel CC, Korttila K, Abdalla M, et al:: A Factorial Trial of Six Interventions for the Prevention of Postoperative Nausea and Vomiting. N Engl J Med. 2004 350(24): 2441-51.

PubMed Abstract | Publisher Full Text | Free Full Text

123. Tang J, Wang B, White PF, et al.: The effect of timing of ondansetron administration on its efficacy, cost-effectiveness, and cost-benefit as a prophylactic antiemetic in the ambulatory setting. Anesth Analg. 1998; 86(2): 274-82.

PubMed Abstract | Publisher Full Text

124. White $P F$, Tang J, Hamza MA, et al.: The use of oral granisetron versus intravenous ondansetron for antiemetic prophylaxis in patients undergoing laparoscopic surgery: The effect on emetic symptoms and quality of recovery. Anesth Analg. 2006; 102(5): 1387-93. PubMed Abstract | Publisher Full Text

125. Kamali A, Ahmadi L, Shokrpour M, et al.: Investigation of Ondansetron, Haloperidol, and Dexmedetomidine Efficacy for Prevention of Postoperative Nausea and Vomiting In Patients with Abdominal Hysterectomy. Open Access Maced J Med Sci. 2018; 6(9): 1659-63. PubMed Abstract | Publisher Full Text | Free Full Text

126. Isazadehfar $\mathrm{K}$, Entezariasl M, Shahbazzadegan $\mathrm{B}$, et al:: The Comparative Study of Ondansetron and Metoclopramide Effects in Reducing Nausea and Vomiting After Laparoscopic Cholecystectomy. Acta Med Iran. 2017; 55(4): 254-8. PubMed Abstract

127. Bai B, Pei LJ, Zhang YL, et al.: Adding Ondansetron in Morphine Intravenous Analgesia Pump for Prevention of Postoperative Nausea and Vomiting in Women. Zhongguo Yi Xue Ke Xue Yuan Xue Bao. 2018; 40(3): 373-7. PubMed Abstract | Publisher Full Text

128. Pazoki S, Modir $\mathrm{H}$, Kamali $\mathrm{A}$, et al: Ondansetron $8 \mathrm{mg}$ and $4 \mathrm{mg}$ with norma saline against post-operative headache and nausea/vomiting after spinal anesthesia: A randomized double-blind trial. Med Gas Res. 2018; 8(2): 48-53. PubMed Abstract | Publisher Full Text | Free Full Text

129. Koyuncu O, Leung S, You J, et al.: The effect of ondansetron on analgesic efficacy of acetaminophen after hysterectomy: A randomized double blinded placebo controlled trial. J Clin Anesth. 2017; 40: 78-83. PubMed Abstract | Publisher Full Text

130. Zhu M, Zhou C, Huang B, et al.: Granisetron plus dexamethasone for prevention of postoperative nausea and vomiting in patients undergoing laparoscopic surgery: A meta-analysis. J Int Med Res. 2017; 45(3): 904-11. PubMed Abstract | Publisher Full Text | Free Full Text

131. Lee WS, Lee KB, Lim S, et al.: Comparison of palonosetron, granisetron, and ramosetron for the prevention of postoperative nausea and vomiting after laparoscopic gynecologic surgery: A prospective randomized trial. $B M C$ Anesthesiol. 2015; 15: 121. PubMed Abstract | Publisher Full Text | Free Full Text

132. Tahir S, Mir AA, Hameed A: Comparison of Palonosetron with Granisetron for Prevention of Postoperative Nausea and Vomiting in Patients Undergoing Laparoscopic Abdominal Surgery. Anesth Essays Res. 2018; 12(3): 636-43. PubMed Abstract | Publisher Full Text | Free Full Text

133. White PF: Ambulatory Anesthesia and Surgery. London,WB Saunders, 1997; 442.

134. Hahm TS, Ko JS, Choi SJ, et al.: Comparison of the prophylactic anti-emetic efficacy of ramosetron and ondansetron in patients at high-risk for postoperative nausea and vomiting after total knee replacement. Anaesthesia. 2010; 65(5): 500-4. PubMed Abstract | Publisher Full Text

135. Joo J, Park S, Park HJ, et al.: Ramosetron versus ondansetron for 
postoperative nausea and vomiting in strabismus surgery patients. $B M C$ Anesthesiol. 2016; 16(1): 41.

PubMed Abstract | Publisher Full Text | Free Full Text

136. Gao C, Li B, Xu L, et al.: Efficacy and safety of ramosetron versus ondansetron for postoperative nausea and vomiting after general anesthesia: A meta-analysis of randomized clinical trials. Drug Des Devel Ther. 2015; 9: 2343-50.

PubMed Abstract | Publisher Full Text | Free Full Text

137. Yokoi A, Mihara T, Ka K, et al.: Comparative efficacy of ramosetron and ondansetron in preventing postoperative nausea and vomiting: An updated systematic review and meta-analysis with trial sequential analysis. PLoS One. 2017: 12: e0186006. PubMed Abstract | Publisher Full Text | Free Full Text

138. Choi YS, Sohn HM, Do SH, et al.: Comparison of ramosetron and ondansetron for the treatment of established postoperative nausea and vomiting after laparoscopic surgery: A prospective, randomized, double-blinded multicenter trial. Ther Clin Risk Manag. 2018; 14: 601-6. PubMed Abstract | Publisher Full Text | Free Full Text

139. Pinsornsak P, Teeyaphudit M, Ruetiwarangkoon C, et al:: Comparison of Ramosetron With Ondansetron for Prevention of Intrathecal MorphineInduced Nausea and Vomiting After Primary Total Knee Arthroplasty: A Randomized Control Trial. J Arthroplasty. 2017; 32(3): 1040-3. PubMed Abstract | Publisher Full Text

140. Park HE, Kim MK, Kang WK: Efficacy and Safety of Ramosetron Injection for Nausea and Vomiting in Colorectal-Cancer Patients Undergoing a Laparoscopic Colectomy: A Randomized, Double-Blind, Comparative Study. Ann Coloproctol. 2018; 34(1): 36-41. PubMed Abstract | Publisher Full Text | Free Full Text

141. Lee B, Kim K, Suh DH, et al.: Efficacy of Single-dose and 2-dose Intravenous Administration of Ramosetron in Preventing Postoperative Nausea and Vomiting After Laparoscopic Gynecologic Operation: A Randomized Double-blind, Placebo-controlled, Phase 2 Trial. Surg Laparosc Endosc Percutan Tech. 2017; 27(3): 183-8. PubMed Abstract | Publisher Full Text

142. Wangnamthip $S$, Chinachoti $T$, Amornyotin S, et al: A Randomized PlaceboControlled Trial of Oral Ramosetron for Prevention of Post Operative Nausea and Vomiting after Intrathecal Morphine in Patients Undergoing Gynecological Surgery. J Med Assoc Thai. 2016; 99(5): 455-61. PubMed Abstract

143. Singh PM, Borle A, Gouda D, et al.: Efficacy of palonosetron in postoperative nausea and vomiting (PONV)-a meta-analysis. J Clin Anesth. 2016; 34: 459-82. PubMed Abstract | Publisher Full Text

144. Ahn EJ, Choi GJ, Kang H, et al.: Comparison of Ramosetron with Palonosetron for Prevention of Postoperative Nausea and Vomiting in Patients Receiving Opioid-Based Intravenous Patient-Controlled Analgesia after Gynecological Laparoscopy. Biomed Res Int. 2017; 2017: 9341738. PubMed Abstract | Publisher Full Text | Free Full Text

145. Carvalho Braga EL, Figueiredo NV, Barrucand L, et al:: Use of palonosetro and ondansetron in the prophylaxis of postoperative nausea and vomiting in women 60 years of age or older undergoing laparoscopic cholecystectomy: A randomised double-blind study. Eur J Anaesthesiol. 2019; 36(3): 241-2.

PubMed Abstract | Publisher Full Text | Faculty Opinions Recommendation

146. Liu Q, Zhou C, Bao Z, et al.: Effects of palonosetron and ondansetron on preventing nausea and vomiting after laparoscopic surgery. J Int Med Res. 2018; 46(1): 411-20.

PubMed Abstract | Publisher Full Text | Free Full Text

147. Reddy G, Manjusruthi B, Jyothsna G: Postoperative nausea and vomiting prophylaxis: A comparative study of ramosetron and palonosetron in patients undergoing laparoscopic cholecystectomy - A prospective randomized trial. Anesth Essays Res. 2019; 13: 68-72. PubMed Abstract | Publisher Full Text | Free Full Text Faculty Opinions Recommendation

148. Kim MS, Park JH, Choi YS, et al.: Efficacy of Palonosetron vs. Ramosetron for the Prevention of Postoperative Nausea and Vomiting: A Meta-Analysis of Randomized Controlled Trials. Yonsei Med J. 2017; 58(4): 848-58. PubMed Abstract | Publisher Full Text | Free Full Text

149. Wang Jl, Ho ST, Lee SC, et al.: The use of dexamethasone for preventing postoperative nausea and vomiting in females undergoing thyroidectomy: A dose-ranging study. Anesth Analg. 2000; 91(6): 1404-7. PubMed Abstract | Publisher Full Text

150. Maitra S, Som A, Baidya DK, et al.: Comparison of Ondansetron and Dexamethasone for Prophylaxis of Postoperative Nausea and Vomiting in Patients Undergoing Laparoscopic Surgeries: A Meta-Analysis of Randomized Controlled Trials. Anesthesiol Res Pract. 2016; 2016: 7089454 Randomized Controlled Trials. Anesthesiol Res Pract. 2016;
PubMed Abstract | Publisher Full Text | Free Full Text

151. Parthasarathy P, Babu K, Raghavendra Rao RS, et al.: The Effect of Single-dose Intravenous Dexamethasone on Postoperative Pain and Postoperative Nausea and Vomiting in Patients Undergoing Surgery under Spinal Anesthesia: A Double-blind Randomized Clinical Study. Anesth Essays Res. 2018; 12(2): 313-7.

PubMed Abstract | Publisher Full Text | Free Full Text

152. Ormel G, Romundstad L, Lambert-Jensen P, et al.: Dexamethasone has additive effect when combined with ondansetron and droperidol for treatment of established PONV. Acta Anaesthesiol Scand. 2011; 55(10): 1196-205. PubMed Abstract | Publisher Full Text

153. Murphy GS, Szokol JW, Greenberg SB, et al.: Preoperative dexamethasone enhances quality of recovery after laparoscopic cholecystectomy: Effect on in-hospital and postdischarge recovery outcomes. Anesthesiology. 2011; 114(4): 882-90.

PubMed Abstract | Publisher Full Text

154. Ismail EA, Bakri MH, Abd-Elshafy SK: Dexamethasone alone versus in combination with intra-operative super-hydration for postoperative nausea and vomiting prophylaxis in female patients undergoing laparoscopic cholecystectomy: A randomized clinical trial. Korean J Anesthesiol. 2017: 70(5): 535-541.

PubMed Abstract | Publisher Full Text | Free Full Text

155. Awad K, Ahmed H, Abushouk AI, et al.: Dexamethasone combined with other antiemetics versus single antiemetics for prevention of postoperative nausea and vomiting after laparoscopic cholecystectomy: An updated systematic review and meta-analysis. Int J Surg. 2016; 36(Pt A): 152-63. PubMed Abstract | Publisher Full Text

156. Kumar A, Patodia M, Pandove $\mathrm{P}$, et al.: A randomized, placebo-controlled study evaluating preventive role of ondansetron, dexamethasone and ondansetron plus dexamethasone for postoperative nausea and vomiting (PONV) in patients undergoing laparoscopic cholecystectomy. Journal International Medical Sciences Academy 2013; 26(4): 217-8. Reference Source

157. Coloma M, White PF, Markowitz SD, et al: Dexamethasone in Combination With Dolasetron for Prophylaxis in the Ambulatory Setting: Effect on Outcome After Laparoscopic Cholecystectomy. Anesthesiology. 2002; 96(6): $1346-50$

PubMed Abstract | Publisher Full Text

158. Amer M, Uddin S, Rasheed F: Comparison of use of metoclopramide alone and in combination with dexamethasone for prevention of postoperative nausea and vomiting in laparoscopic cholecystectomy. Pak J Med Health SCi. 2012; 6(3): 626-8.

Reference Source

159. Jo YY, Lee JW, Shim JK, et al.: Ramosetron, dexamethasone, and their combination for the prevention of postoperative nausea and vomiting in women undergoing laparoscopic cholecystectomy. Surg Endosc. 2012; 26(8): 2306-11.

PubMed Abstract | Publisher Full Text

160. Ahsan K, Abbas N, Naqvi SMN, et al.: Comparison of efficacy of ondansetron and dexamethasone combination and ondansetron alone in preventing postoperative nausea and vomiting after laparoscopic cholecystectomy. Pak Med Assoc. 2014; 64(3): 242-6. PubMed Abstract

161. Ko-Iam W, Sandhu T, Paiboonworachat S, et al.: Metoclopramide, versus its combination with dexamethasone in the prevention of postoperative nausea and vomiting after laparoscopic cholecystectomy: A double-blind randomized controlled trial. J Med Assoc Thai. 2015; 98(3): 265-72. PubMed Abstract

162. Bala I, Bharti N, Murugesan S, et al: Comparison of palonosetron with palonosetron-dexamethasone combination for prevention of postoperative nausea and vomiting in patients undergoing laparoscopic cholecystectomy. Minerva Anestesiol. 2014; 80(7): 779-84. PubMed Abstract

163. Alia I, Gillani M, Hanif A, et al: Comparison of ondansetron and combination of ondansetron and dexamethasone for prevention of post-operative nausea and vomiting in patients undergoing elective laparoscopic cholecystectomy. PakJ Med Health Sci. 2015; 9(4): 1387-89. Reference Source

164. Gupta R, Srivastava S, Dhiraaj S, et al.: Minimum effective dose of dexamethasone in combination with midazolam as prophylaxis against postoperative nausea and vomiting after laparoscopic cholecystectomy. Anesth Essays Res. 2018; 12(2): 396-401. PubMed Abstract | Publisher Full Text | Free Full Text

165. Cortés-Flores AO, Jiménez-Tornero J, Morgan-Villela G, et al.: Effects of preoperative dexamethasone on postoperative pain, nausea, vomiting and respiratory function in women undergoing conservative breast surgery for cancer: Results of a controlled clinical trial. Eur J Cancer Care (Engl). 2018; 27(1). PubMed Abstract | Publisher Full Text

166. DREAMS Trial Collaborators and West Midlands Research Collaborative: Dexamethasone versus standard treatment for postoperative nausea and vomiting in gastrointestinal surgery: Randomised controlled trial (DREAMS Trial). BMJ. 2017; 357: j1455. PubMed Abstract | Publisher Full Text | Free Full Text

167. Xu B, Ma J, Huang $\mathrm{Q}$, et al: Two doses of low-dose perioperative dexamethasone improve the clinical outcome after total knee arthroplasty: A randomized controlled study. Knee Surg Sports Traumatol Arthrosc. 2018; 26(5): 1549-56. PubMed Abstract | Publisher Full Text

168. Fan Z, Ma J, Kuang M, et al.: The efficacy of dexamethasone reducing postoperative pain and emesis after total knee arthroplasty: A systematic 
review and meta-analysis. Int J Surg. 2018; 52: 149-55.

PubMed Abstract | Publisher Full Text

169. Ismail EA, Abo Elfadl GM, Bahloul M: Comparison of intraperitoneal versus intravenous dexamethasone on postoperative nausea and vomiting after gynecological laparoscopy: A randomized clinical trial. Korean J Anesthesiol. 2019; 72(1): 47-52.

PubMed Abstract | Publisher Full Text | Free Full Text Faculty Opinions Recommendation

170. Seki H, Wakamiya $\mathrm{R}$, Ihara $\mathrm{N}$, et al: The Effect of Dexamethasone on Postoperative Nausea and Vomiting in Posterior Correction and Fusion Surgery for Adolescent Idiopathic Scoliosis. Masui. 2017; 66(3): 298-302. PubMed Abstract

171. Sane S, Hasanlui MV, Abbasivash R, et al.: Comparing the effect of intravenous dexamethasone, intravenous ondansetron, and their combination on nausea and vomiting in cesarean section with spinal anesthesia. Adv Biomed Res. 2015; 4: 230. PubMed Abstract | Publisher Full Text | Free Full Tex

172. W Wakamiya R, Seki H, Ideno S, et al.: Effects of prophylactic dexamethasone on postoperative nausea and vomiting in scoliosis correction surgery: A double-blind, randomized, placebo-controlled clinical trial. Sci Rep. 2019; 9(1): 2119.

PubMed Abstract | Publisher Full Text | Free Full Text | Faculty Opinions Recommendation

173. Reibaldi M, Fallico M, Longo A, et al.: Efficacy of Three Different Prophylactic Treatments for Postoperative Nausea and Vomiting after Vitrectomy: A Randomized Clinical Trial. J Clin Med. 2019; 8(3): 391. PubMed Abstract | Publisher Full Text | Free Full Text | Faculty Opinions Recommendation

174. Cho E, Kim DH, Shin S, et al.: Efficacy of Palonosetron-Dexamethasone Combination Versus Palonosetron Alone for Preventing Nausea and Vomiting Related to Opioid-Based Analgesia: A Prospective, Randomized, Double-blind Trial. Int J Med Sci. 2018; 15(10): 961-8. PubMed Abstract | Publisher Full Text | Free Full Text

175. Frelich M, Divák J, Vodička V, et al.: Dexamethasone Reduces the Incidence of Postoperative Nausea and Vomiting in Children Undergoing Endoscopic Adenoidectomy under General Anesthesia Without Increasing the Risk of Postoperative Hemorrhage. Med Sci Monit. 2018; 24: 8430-8. PubMed Abstract | Publisher Full Text | Free Full Text

176. Sayed JA, Riad MAF, Ali MOM: Comparison of dexamethasone or intravenous fluids or combination of both on postoperative nausea, vomiting and pain in pediatric strabismus surgery. J Clin Anesth. 2016; 34: 136-42. PubMed Abstract | Publisher Full Text

177. Haapanen A, Thorén $\mathrm{H}$, Törnwall J, et al.: Postoperative nausea and vomiting in facial fracture patients: A Randomized and controlled trial on the effect of dexamethasone. Int J Oral Maxillofac Surg. 2017; 46(10): 1267-70. PubMed Abstract | Publisher Full Text

178. Kleif J, Kirkegaard A, Vilandt J, et al.: Randomized clinical trial of preoperative dexamethasone on postoperative nausea and vomiting after laparoscopy for suspected appendicitis. Br J Surg. 2017; 104(4): 384-92. PubMed Abstract | Publisher Full Text

179. Thongrong $C$, Chullabodhi $P$, Kasemsiri $P$, et al.: Effects of Intraoperative Dexamethasone and Ondansetron on Postoperative Nausea and Vomiting in Microvascular Decompression Surgery: A Randomized Controlled Study. Anesthesiology Research and Practice. 2018; 2018: 6297362. PubMed Abstract | Publisher Full Text | Free Full Text

180. Singh PM, Borle A, Panwar R, et al.: Perioperative antiemetic efficacy of dexamethasone versus 5-HT3 receptor antagonists: A meta-analysis and trial sequential analysis of randomized controlled trials. Eur J Clin Pharmacol. 2018; 74(10): 1201-14. PubMed Abstract | Publisher Full Text

181. Wasfie T, Tabatabai A, Hedni R, et al.: Effect of intra-operative single dose of dexamethasone for control of post-operative nausea and vomiting on the control of glucose levels in diabetic patients. Am J Surg. 2018; 215(3): 488-90. PubMed Abstract | Publisher Full Text

182. Aasboe V, Raeder JC, Groegaard B: Betamethasone Reduces Postoperative Pain and Nausea After Ambulatory Surgery. Anesth Analg. 1998; 87(2): 319-23. PubMed Abstract | Publisher Full Text

183. Thagaard KS, Jensen $\mathrm{HH}$, Raeder J: Analgesic and antiemetic effect of ketorolac vs. betamethasone or dexamethasone after ambulatory surgery. Acta Anaesthesiol Scand. 2007; 51(3): 271-7. PubMed Abstract | Publisher Full Text

184. Olanders $\mathrm{KJ}$, Lundgren GAE, Johansson AMG: Betamethasone in prevention of postoperative nausea and vomiting following breast surgery.J Clin Anesth. 2014; 26(6): 461-5. PubMed Abstract | Publisher Full Text

185. Champion S, Zieger L, Hemery C: Prophylaxis of postoperative nausea and vomiting after cardiac surgery in high-risk patients: A randomized controlled study. Ann Card Anaesth. 2018; 21(1): 8-14. PubMed Abstract | Publisher Full Text | Free Full Tex

186. Nordin L, Nordlund A, Lindqvist A, et al: Corticosteroids or Not for Postoperative Nausea: A Double-Blinded Randomized Study.J Gastrointest Surg. 2016; 20(8): 1517-22. PubMed Abstract | Publisher Full Text
187. Liu M, Zhang H, Du BX, et al.: Neurokinin-1 Receptor Antagonists in Preventing Postoperative Nausea and Vomiting: A Systematic Review and Meta-Analysis. Medicine (Baltimore). 2015; 94(19): e762. PubMed Abstract | Publisher Full Text | Free Full Text

188. Gesztesi Z, Scuderi PE, White PF, et al.: Substance P (Neurokinin-1) antagonist prevents postoperative vomiting after abdominal hysterectomy procedures. Anesthesiology. 2000; 93(4): 931-7. PubMed Abstract | Publisher Full Text

189. Diemunsch P, Gan TJ, Philip BK, et al:: Single-dose aprepitant vs ondansetron for the prevention of postoperative nausea and vomiting: A randomized, double-blind Phase III trial in patients undergoing open abdominal surgery. BrJ Anaesth. 2007; 99(2): 202-11. PubMed Abstract | Publisher Full Text

190. Milnes V, Gonzalez A, Amos V: Aprepitant: A New Modality for the Prevention of Postoperative Nausea and Vomiting: An Evidence-Based Review. J Perianesth Nurs. 2015; 30(5): 406-17. PubMed Abstract | Publisher Full Text

191. Gan TJ, Apfel CC, Kovac A, et al.: A Randomized, Double-Blind Comparison of the NK1 Antagonist, Aprepitant, Versus Ondansetron for the Prevention of Postoperative Nausea and Vomiting. Anesth Analg. 2007; 104(5): 1082-9. PubMed Abstract | Publisher Full Text

192. Emami H, Hematti S, Saeidian SM, et al.: The efficacy of combination of ondansetron and aprepitant on preventing the radiotherapy-induced nausea and vomiting. J Res Med Sci. 2015; 20(4): 329-33. PubMed Abstract | Free Full Text

193. Bilgen S, Kizilcik N, Haliloglu M, et al.: Effect of the DexamethasoneOndansetron Combination Versus Dexamethasone-Aprepitant Combination to Prevent Postoperative Nausea and Vomiting. Turk J Anaesth Reanim. 2018; 46(5): 373-80.

PubMed Abstract | Publisher Full Text | Free Full Text

194. Habib AS, Keifer JC, Borel CO, et al.: A comparison of the combination of aprepitant and dexamethasone versus the combination of ondansetron and dexamethasone for the prevention of postoperative nausea and vomiting in patients undergoing craniotomy. Anesth Analg. 2011; 112(4): 813-8.

PubMed Abstract | Publisher Full Text

195. Jeyabalan S, Thampi S, Karuppusami R, et al.: Comparing the efficacy of aprepitant and ondansetron for the prevention of postoperative nausea and vomiting (PONV): A double blinded, randomised control trial in patients undergoing breast and thyroid surgeries. Indian J Anaesth. 2019; 63(4): 289-294.

PubMed Abstract | Publisher Full Text | Free Full Text | Faculty Opinions Recommendation

196. Yoo JH, Im Kim S, Chung JW, et al.: Aprepitant in combination with palonosetron for the prevention of postoperative nausea and vomiting in female patients using intravenous patient-controlled analgesia. Korean J Anesthesiol. 2018; 71(16): 440-446. PubMed Abstract | Publisher Full Text | Free Full Text

197. Salman FT, DiCristina C, Chain A, et al.: Pharmacokinetics and pharmacodynamics of aprepitant for the prevention of postoperative nausea and vomiting in pediatric subjects. J Pediatr Surg. 2019; 54(7): 1384-90. PubMed Abstract | Publisher Full Text | Faculty Opinions Recommendation

198. Atsuta J, Inoue S, Tanaka Y, et al.: Fosaprepitant versus droperidol for prevention of PONV in craniotomy: A randomized double-blind study. Anesth. 2017: 31(1): 82-8. PubMed Abstract | Publisher Full Text

199. Soga T, Kume K, Kakuta N, et al.: Fosaprepitant versus ondansetron for the prevention of postoperative nausea and vomiting in patients who undergo gynecologic abdominal surgery with patient-controlled epidural analgesia: A prospective, randomized double-blind study. J Anesth. 2015; 29(5):696-701. PubMed Abstract | Publisher Full Text

200. White PF: Droperidol: A cost-effective antiemetic for over thirty years. Anesth Analg. 2002; 95(4): 789-90. PubMed Abstract | Publisher Full Text

201. Fortney JT, Gan TJ, Graczyk S, et al.: A Comparison of the Efficacy, Safety, and Patient Satisfaction of Ondansetron Versus Droperidol as Antiemetics for Elective Outpatient Surgical Procedures. Anesth Analg. 1998; 86(4): 731-8. PubMed Abstract | Publisher Full Text

202. Hill RP, Lubarsky DA, Phillips-Bute B, et al.: Cost-effectiveness of prophylactic antiemetic therapy with ondansetron, droperidol, or placebo. Anesthesiology. 2000; 92(4): 958-67.

PubMed Abstract | Publisher Full Text

203. White PF: Prevention of postoperative nausea and vomiting--a multimodal solution to a persistent problem. N EnglJ Med. 2004; 350(24): 2511-2. PubMed Abstract | Publisher Full Text

204. Tricco AC, Soobiah C, Blondal E, et al.: Comparative safety of serotonin (5-HT receptor antagonists in patients undergoing surgery: A systematic review and network meta-analysis. BMC Med. 2015: 13: 142 PubMed Abstract | Publisher Full Text | Free Full Text

205. Flubacher P, Fournier N, Cherpillod J, et al.: A randomised controlled trial of placebo, droperidol or ondansetron to prevent nausea and vomiting after tonsillectomy in children receiving dexamethasone. Anaesthesia. 2017; 72(7): $859-63$.

PubMed Abstract | Publisher Full Tex 
206. Charton A, Greib N, Ruimy A, et al.: Incidence of akathisia after postoperative nausea and vomiting prophylaxis with droperidol and ondansetron in outpatient surgery: A multicentre controlled randomised trial. Eur Anaesthesiol. 2018; 35(12): 966-71. PubMed Abstract | Publisher Full Text

207. Bourdaud N, François C, Jacqmarcq O, et al.: Addition of droperidol to prophylactic ondansetron and dexamethasone in children at high risk for postoperative vomiting. A randomized, controlled, double-blind study. $\mathrm{Br}$ Anaesth. 2017: 118(6): 918-23. PubMed Abstract | Publisher Full Text

208. Singh PM, Borle A, Makkar JK, et al.: Haloperidol Versus 5-HT ${ }_{3}$ Receptor Antagonists for Postoperative Vomiting and QTc Prolongation: A Noninferiority Meta-Analysis and Trial Sequential Analysis of Randomized Controlled Trials. J Clin Pharmacol. 2018; 58(2): 131-43. PubMed Abstract | Publisher Full Text

209. Brettner F, Janitza S, Prüll K, et al.: Gender-Specific Differences in LowDose Haloperidol Response for Prevention of Postoperative Nausea and Vomiting: A Register-Based Cohort Study. PLoS One. 2016; 11(1): e0146746. PubMed Abstract | Publisher Full Text | Free Full Text

210. Mishriky BM, Habib AS: Metoclopramide for nausea and vomiting prophylaxis during and after Caesarean delivery: A systematic review and meta-analysis. Br J Anaesth. 2012; 108(3): 374-83. PubMed Abstract | Publisher Full Text

211. Habib AS, Kranke P, Bergese SD, et al.: Amisulpride for the Rescue Treatment of Postoperative Nausea or Vomiting in Patients Failing Prophylaxis: A Randomized, Placebo-controlled Phase III Trial. Anesthesiology. 2019; 130(2): 203-12. PubMed Abstract | Publisher Full Text | Faculty Opinions Recommendation

212. Candiotti KA, Kranke P, Bergese SD, et al.: Randomized, Double-Blind, Placebo-Controlled Study of Intravenous Amisulpride as Treatment of Established Postoperative Nausea and Vomiting in Patients Who Have Had No Prior Prophylaxis. Anesth Analg. 2019; 128(6): 1098-105. PubMed Abstract | Publisher Full Text | Faculty Opinions Recommendation

213. Gan TJ, Kranke P, Minkowitz HS, et al.: Intravenous Amisulpride for the Prevention of Postoperative Nausea and Vomiting: Two Concurrent, Randomized, Double-blind, Placebo-controlled Trials. Anesthesiology. 2017; 126(2): 268-75.

PubMed Abstract | Publisher Full Text

214. Kranke P, Bergese SD, Minkowitz HS, et al.: Amisulpride Prevents Postoperative Nausea and Vomiting in Patients at High Risk: A Randomized, Double-blind, Placebo-controlled Trial. Anesthesiology. 2018; 128(6): 1099-106. PubMed Abstract | Publisher Full Text

215. White PF, Tang J, Song D, et al.: Transdermal scopolamine: An alternative to ondansetron and droperidol for the prevention of postoperative and postdischarge emetic symptoms. Anesth Analg. 2007; 104(1): 92-6. PubMed Abstract | Publisher Full Text

216. Apfel CC, Zhang K, George E, et al.: Transdermal scopolamine for the prevention of postoperative nausea and vomiting: A systematic review and meta-analysis. Clin Ther. 2010; 32(12): 1987-2002. PubMed Abstract | Publisher Full Text

217. Pergolizzi JV, Philip BK, Leslie JB, et al.: Perspectives on transdermal scopolamine for the treatment of postoperative nausea and vomiting J Clin Anesth. 2012; 24(4): 334-45. PubMed Abstract | Publisher Full Text

218. Kassel L, Nelson M, Shine J, et al.: Scopolamine Use in the Perioperative Patient: A Systematic Review. AORN J. 2018; 108(3): 287-95. PubMed Abstract | Publisher Full Text

219. Cangemi DJ, Kuo B: Practical Perspectives in the Treatment of Nausea and Vomiting. J Clin Gastroenterol. 2019; 53(3): 170-8. PubMed Abstract | Publisher Full Text

220. Suzuki T, Inokuchi R, Hanaoka K, et al.: Dexmedetomidine use during epiduroscopy reduces fentanyl use and postoperative nausea and vomiting: A single-center retrospective study. SAGE Open Med. 2018; 6: 2050312118756804.

PubMed Abstract | Publisher Full Text | Free Full Text

221. Geng ZY, Liu YF, Wang SS, et al.: Intra-operative Dexmedetomidine Reduces Early Postoperative Nausea but Not Vomiting in Adult Patients After Gynaecological Laparoscopic Surgery: A Randomised Controlled Trial. Eur J Anaesthesiol. 2016; 33(10): 761-6. PubMed Abstract | Publisher Full Tex

222. Jin S, Liang DD, Chen C, et al.: Dexmedetomidine prevent postoperative nausea and vomiting on patients during general anesthesia: A PRISMAcompliant meta analysis of randomized controlled trials. Medicine (Baltimore). 2017: 96(1): e5770.

PubMed Abstract | Publisher Full Text | Free Full Text

223. Ajori L, Nazari L, Mazloomfard MM, et al.: Effects of gabapentin on postoperative pain, nausea and vomiting after abdominal hysterectomy: A double blind randomized clinical trial. Arch Gynecol Obstet. 2012; 285(3): $677-82$

PubMed Abstract | Publisher Full Text

224. Grant MC, Lee H, Page AJ, et al.: The Effect of Preoperative Gabapentin on Postoperative Nausea and Vomiting: A Meta-Analysis. Anesth Analg. 2016
122(4): $976-85$.

PubMed Abstract | Publisher Full Text

225. Agrawal N, Chatterjee C, Khandelwal M, et al.: Comparative study of preoperative use of oral gabapentin, intravenous dexamethasone and their combination in gynaecological procedure. Saudi J Anaesth. 2015; 9(4): 413-7. PubMed Abstract | Publisher Full Text | Free Full Text

226. Tsai KC, Yang YL, Fan PC: Gabapentin for Postoperative Vomiting in Children Requiring Posterior Fossa Tumor Resection. Pediatr Neonatol. 2015; 56(3): 351-4. PubMed Abstract | Publisher Full Text

227. Grant MC, Betz M, Hulse M, et al.: The Effect of Preoperative Pregabalin on Postoperative Nausea and Vomiting: A Meta-analysis. Anesth Analg. 2016; 123(5): 1100-7.

PubMed Abstract | Publisher Full Text

228. Wang YM, Xia M, Shan N, et al.: Pregabalin Can Decrease Acute Pain and Postoperative Nausea and Vomiting in Hysterectomy: A Meta-Analysis. Medicine (Baltimore). 2017; 96(31): e7714

PubMed Abstract | Publisher Full Text | Free Full Text

229. White PF, Tufanogullari B, Taylor J, et al.: The effect of pregabalin on preoperative anxiety and sedation levels: A dose-ranging study. Anesth Analg. 2009; 108(4): 1140-5.

PubMed Abstract | Publisher Full Text | Faculty Opinions Recommendation

230. Kizilcik N, Bilgen S, Menda F, et al.: Comparison of DexamethasoneDimenhydrinate and Dexamethasone-Ondansetron in Prevention of Nausea and Vomiting in Postoperative Patients. Aesthetic Plast Surg. 2017; 41(1): 204-10.

PubMed Abstract | Publisher Full Text

231. Malamood M, Roberts A, Kataria R, et al.: Mirtazapine for symptom control in refractory gastroparesis. Drug Des Devel Ther. 2017; 11: 1035-41. PubMed Abstract | Publisher Full Text | Free Full Text

232. Dhattacharjee D, Doleman B, Lund J, et al.: Mirtazapine for Postoperative Nausea and Vomiting: Systematic Review, Meta-analysis, and Trial Sequential Analysis. J Perianesth Nurs. 2019; 34(4): 680-90. PubMed Abstract | Publisher Full Text | Faculty Opinions Recommendation

233. Heidari SM, Saryazdi H, Saghaei M: Effect of intravenous midazolam premedication on postoperative nausea and vomiting after cholecystectomy. Acta Anaesthesiol Taiwan. 2004; 42(2): 77-80. PubMed Abstract

234. Jung JS, Park JS, Kim SO, et al:: Prophylactic antiemetic effect of midazolam after middle ear surgery. Otolaryngol Head Neck Surg. 2016; 137(5): 753-6. PubMed Abstract | Publisher Full Text

235. Shirdashtzadeh N, Eshraghi N, Eshraghi A: Comparison of parenteral promethazine versus midazolam effect as a preoperative medication on postoperative nausea and vomiting after appendectomy. Caspian J Intern Med. 2011; 2(3): 270-3. PubMed Abstract | Free Full Text

236. Kranke $\mathrm{P}$, Eberhart LHJ: Possibilities and limitations in the pharmacologica management of postoperative nausea and vomiting. Eur J Anaesthesiol. 2011; 28(11): 758-65.

PubMed Abstract | Publisher Full Text

237. Honarmand A, Safavi M, Khalili G, et al.: Prophylactic administration of haloperidol plus midazolam reduces postoperative nausea and vomiting better than using each drug alone in patients undergoing middle ear surgery. Saudi J Anaesth. 2012; 6(2): 145-51. PubMed Abstract | Publisher Full Text | Free Full Text

238. Kim WJ, Kang $\mathrm{H}$, Shin HY, et al.: Ramosetron, midazolam, and combination of ramosetron and midazolam for prevention of postoperative nausea and vomiting: A prospective, randomized, double-blind study. J Int Med Res. 2013; 41(4): 1203-13. PubMed Abstract | Publisher Full Text

239. Park EY, Lee SK, Kang MH, et al.: Comparison of ramosetron with combined ramosetron and midazolam for preventing postoperative nausea and vomiting in patients at high risk following laparoscopic gynaecological surgery. J Int Med Res. 2013; 41(3): 654-63. PubMed Abstract | Publisher Full Text

240. Abdelhamid S, Kamel M: A prospective controlled study to assess the antiemetic effect of midazolam following intragastric balloon insertion. J Anaesthesiol Clin Pharmacol. 2014; 30(3): 383-6. PubMed Abstract | Publisher Full Text | Free Full Text

241. Grant MC, Kim J, Page AJ, et al.: The Effect of Intravenous Midazolam on Postoperative Nausea and Vomiting: A Meta-Analysis. Anesth Analg. 2016; 122(3): 656-63.

PubMed Abstract | Publisher Full Text

242. Jabaley CS, Gray DW, Budhrani GS, et al.: Chronic Atypical Antipsychotic Use Is Associated With Reduced Need for Postoperative Nausea and Vomiting Rescue in the Postanesthesia Care Unit: A Propensity-Matched Retrospective Observational Study. Anesth Analg. 2020; 130(1): 141-50. PubMed Abstract | Publisher Full Text | Faculty Opinions Recommendation

243. Kang HY, Park SW, Lee S, et al.: Effect of prophylactic palonosetron and sugammadex on postoperative nausea and vomiting in patients undergoing microvascular decompression under propofol-maintained anesthesia: A retrospective observational study. Medicine (Baltimore). 2018. 
97(46): e13237.

PubMed Abstract | Publisher Full Text | Free Full Text

244. Aksoy M, İnce İ, Ahıskalıoğlu A, et al.: Effect of intravenous preoperative versus postoperative paracetamol on postoperative nausea and vomiting in patients undergoing strabismus surgery: A prospective randomized study. Agri. 2018; 30(1): 1-7.

PubMed Abstract | Publisher Full Text

245. Roberts CA, Shah-Becker S, O'Connell Ferster A, et al: Randomized Prospective Evaluation of Intraoperative Intravenous Acetaminophen in Pediatric Adenotonsillectomy. Otolaryngol Head Neck Surg. 2018; 158(2): 368-74.

PubMed Abstract | Publisher Full Text

246. Levin DN, Dulberg Z, Chan AW, et al.: A randomized-controlled trial of nabilone for the prevention of acute postoperative nausea and vomiting in elective surgery. Can J Anesth. 2017; 64(4): 385-95. PubMed Abstract | Publisher Full Text

247. Ibrahim AS, Aly MG, Thabet ME, et al.: Effect of adding nalbuphine to intrathecal bupivacaine with morphine on postoperative nausea and vomiting and pruritus after elective cesarean delivery: A randomized double blinded study. Minerva Anestesiol. 2019; 85(3): 255-62. PubMed Abstract | Publisher Full Text | Faculty Opinions Recommendation

248. Naba A, Laurent SR, Detroz BJ, et al.: Intravenous Lidocaine Infusion Facilitates Acute Rehabilitation after Laparoscopic Colectomy. Anesthesiology. 2007; 106(1): 11-8. PubMed Abstract | Publisher Full Text | Faculty Opinions Recommendation

249. McKay A, Gottschalk A, Ploppa A, et al.: Systemic lidocaine decreased the perioperative opioid analgesic requirements but failed to reduce discharge time after ambulatory surgery. Anesth Analg. 2009; 109(6): 1805-8. PubMed Abstract | Publisher Full Text

250. Lauwick S, Kim DJ, Mistraletti G, et al.: Functional walking capacity as an outcome measure of laparoscopic prostatectomy: The effect of lidocaine infusion. Br J Anaesth. 2009; 103(2): 213-9. PubMed Abstract | Publisher Full Text

251. Herminghaus A, Wachowiak M, Wilhelm W, et al.: [Intravenous Administration of Lidocaine for Perioperative Analgesia. Review and Recommendations for Practical Usage]. Anaesthesist 2011: 60(2): 152-60. PubMed Abstract | Publisher Full Text

252. Tikuišis R, Miliauskas $P$, Samalavičius NE, et al.: Intravenous lidocaine for post-operative pain relief after hand-assisted laparoscopic colon surgery: A randomized, placebo-controlled clinical trial. Tech Coloproctol. 2014; 18(4): A rando -80 .

PubMed Abstract | Publisher Full Text | Free Full Text

253. Ahn $E$, Kang $H, C h o i ~ G J$, et al.: Intravenous lidocaine for effective pain relief after a laparoscopic colectomy: A prospective, randomized, double-blind, placebo-controlled study. Int Surg. 2015; 100(3): 394-401. PubMed Abstract | Publisher Full Text | Free Full Text

254. Weibel S, Jokinen J, Pace NL, et al.: Efficacy and safety of intravenous lidocaine for postoperative analgesia and recovery after surgery: A systematic review with trial sequential analysis. Br J Anaesth. 2016; 116(6): $770-83$

PubMed Abstract | Publisher Full Text | Faculty Opinions Recommendation

255. Echevarría GC, Altermatt FR, Paredes S, et al.: Intra-operative lidocaine in the prevention of vomiting after elective tonsillectomy in children: $A$ randomised controlled trial. Eur J Anaesthesiol. 2018; 35(5): 343-8. PubMed Abstract | Publisher Full Text

256. Liu Z], Zhang LY, Zheng XG, et al.: [Effects of Continuous Intravenous Intraoperative Lidocaine Infusion on Opioids Consumption and Postoperative Recovery in Patients Undergoing Video-assisted Thoracoscopic Lobectomy]. Zhongguo Yi Xue Ke Xue Yuan Xue Bao. 2018; 40(2): 163-9. PubMed Abstract

257. W Wang T, Liu H, Sun JH, et al.: Efficacy of intravenous lidocaine in improving post-operative nausea, vomiting and early recovery after laparoscopic gynaecological surgery. Exp Ther Med. 2019; 17(6): 4723-4729. PubMed Abstract | Publisher Full Text | Free Full Text | Faculty Opinions Recommendation

258. Dewinter G, Moens P, Fieuws S, et al.: Systemic lidocaine fails to improve postoperative morphine consumption, postoperative recovery and quality of life in patients undergoing posterior spinal arthrodesis. A double-blind, randomized, placebo-controlled trial. Br J Anaesth. 2017; 118(4): 576-85. PubMed Abstract | Publisher Full Text | Faculty Opinions Recommendation

259. Sanchez Munoz MC, de Kock M, Forget P: What is the place of clonidine in anesthesia? Systematic review and meta-analyses of randomized controlled trials. J Clin Anesth. 2017; 38: 140-53. PubMed Abstract | Publisher Full Text

260. Yang Y, Yu LY, Zhang WS: Clonidine versus other adjuncts added to local anesthetics for pediatric neuraxial blocks: A systematic review and metaanalysis. J Pain Res. 2018; 11: 1027-36. PubMed Abstract | Publisher Full Text | Free Full Text

261. Oddby-Muhrbeck E, Eksborg S, Bergendahl HTG, et al:: Effects of Clonidine on Postoperative Nausea and Vomiting in Breast Cancer Surgery. Anesthesiology. 2002; 96(5): 1109-14. PubMed Abstract | Publisher Full Text
262. Masud M, Yeasmeen S, Haque AK, et al:: Role of Oral Clonidine Premedication on Intra-operative Haemodynamics and PONV in Laparoscopic Cholecystectomy. Mymensingh Med J. 2017; 26(4): 913-20. PubMed Abstract

263. Kobayashi $\mathrm{N}$, Ishii S: [Effectiveness of clonidine in postoperative nausea and vomiting--epidural versus oral administration]. Masui. 1997; 46(4): 538-42. PubMed Abstract

264. Segal IS, Jarvis DJ, Duncan SR, et al.: Clinical efficacy of oral-transdermal clonidine combinations during the perioperative period. Anesthesiology. 1991; 74(2): 220-5 PubMed Abstract | Publisher Full Text

265. Allen TK, Mishriky BM, Klinger RY, et al.: The impact of neuraxial clonidine on postoperative analgesia and perioperative adverse effects in women having elective Caesarean section-a systematic review and meta-analysis. BrJ Anaesth. 2018; 120(2): 228-40. PubMed Abstract | Publisher Full Text | Free Full Text

266. Shilpa SNG, Shailaja S, Hilda SS: Comparison of Efficacy of Clonidine versus Ondansetron for Prevention of Nausea and Vomiting Post Thyroidectomy: A Double Blind Randomized Controlled Trial. J Clin Diagn Res. 2015; 9(5): UC01-3.

PubMed Abstract | Publisher Full Text | Free Full Text

267. Samieirad S, Sharifian-Attar A, Eshghpour M, et al.: Comparison of Ondansetron versus Clonidine efficacy for prevention of postoperative pain, nausea and vomiting after orthognathic surgeries: A triple blind randomized controlled trial. Med Oral Patol Oral Cir Bucal. 2018; 23(6): e767-e776. PubMed Abstract | Publisher Full Text | Free Full Text

268. Carvalho FAE, Tenório SB, Shiohara FT, et al.: Randomized study of postcesarean analgesia with intrathecal morphine alone or combined with clonidine. J Clin Anesth. 2016; 33: 395-402. PubMed Abstract | Publisher Full Text

269. Munsterman C, Strauss P: Early Rehydration in Surgical Patients With Prolonged Fasting Decreases Postoperative Nausea and Vomiting. J Perianesth Nurs. 2018; 33(5): 626-31. PubMed Abstract | Publisher Full Text

270. $\mathrm{Kim} \mathrm{HJ}$, Choi SH, Eum D, et al.: Is perioperative colloid infusion mor effective than crystalloid in preventing postoperative nausea and vomiting?: A systematic review and meta-analysis. Medicine (Baltimore). 2019; 98(7): e14339.

PubMed Abstract | Publisher Full Text | Free Full Text | Faculty Opinions Recommendation

271. Apfel CC, Meyer A, Orhan-Sungur M, et al.: Supplemental intravenous crystalloids for the prevention of postoperative nausea and vomiting: Quantitative review. Br J Anaesth. 2012; 108(6): 893-902. PubMed Abstract | Publisher Full Text

272. NJewer JK, Wong MJ, Bird SJ, et al.: Supplemental perioperative intravenous crystalloids for postoperative nausea and vomiting. Cochrane Database Syst Rev. 2019; 3(3): CD012212.

PubMed Abstract | Publisher Full Text | Free Full Text Faculty Opinions Recommendation

273. Ashok V, Bala I, Bharti N, et al.: Effects of intraoperative liberal fluid therapy on postoperative nausea and vomiting in children-A randomized controlled trial. Paediatr Anaesth. 2017; 27(8): 810-5. PubMed Abstract | Publisher Full Text

274. Chauvin C, Schalber-Geyer AS, Lefebvre F, et al.: Early postoperative oral fluid intake in paediatric day case surgery influences the need for opioids and postoperative vomiting: A controlled randomized trialt. Br J Anaesth. 2017; 118(3): 407-14. PubMed Abstract | Publisher Full Text

275. Mishra A, Pandey RK, Sharma A, et al.: Is perioperative administration of $\mathbf{5 \%}$ dextrose effective in reducing the incidence of PONV in laparoscopic cholecystectomy?: A randomized control trial. J Clin Anesth. 2017; 40: 7-10. PubMed Abstract | Publisher Full Text

276. Kim SH, Kim DH, Kim E, et al.: Does perioperative intravenous dextrose reduce postoperative nausea and vomiting? A systematic review and meta-analysis. Ther Clin Risk Manag. 2018; 14: 2003-11. PubMed Abstract | Publisher Full Text | Free Full Text

277. Zorrilla-Vaca A, Marmolejo-Posso D, Stone A, et al.: Perioperative Dextrose Infusion and Postoperative Nausea and Vomiting: A Meta-analysis of Randomized Trials. Anesth Analg. 2019; 129(4): 943-50. PubMed Abstract | Publisher Full Text | Faculty Opinions Recommendation

278. Shibata C, Sasaki I, Naito H, et al:: The herbal medicine Dai-KenchuTou stimulates upper gut motility through cholinergic and 5 hydroxytryptamine 3 receptors in conscious dogs. Surgery. 1999; 126(5): 918-24. PubMed Abstract | Publisher Full Text

279. Abdel-Aziz H, Windeck T, Ploch $M$, et al.: Mode of action of gingerols and shogaols on $5-\mathrm{HT}_{3}$ receptors: Binding studies, cation uptake by the receptor channel and contraction of isolated guinea-pig ileum. Eur Pharmacol. 2006; 530(1-2): 136-43. PubMed Abstract | Publisher Full Text

280. Hu ML, Rayner CK, Wu KL, et al.: Effect of ginger on gastric motility and symptoms of functional dyspepsia. World J Gastroenterol. 2011; 17(1): 105-10. PubMed Abstract | Publisher Full Text | Free Full Text 
281. Fahimi F, Khodadad K, Amini S, et al.: Evaluating the effect of zingiber officinalis on nausea and vomiting in patients receiving Cisplatin based regimens. Iran J Pharm Res. 2011; 10(2): 379-84. PubMed Abstract | Free Full Text

282. Adib-Hajbaghery $M$, Hosseini $F S$ : Investigating the effects of inhaling ginge essence on post-nephrectomy nausea and vomiting. Complement Ther Med. 2015; 23(6): 827-31.

PubMed Abstract | Publisher Full Text

283. Ozgoli G, Goli M, Simbar M: Effects of ginger capsules on pregnancy, nausea, and vomiting. J Altern Complement Med. 2009; 15(3): 243-6. PubMed Abstract | Publisher Full Text

284. Hall HG, Griffiths DL, McKenna LG: The use of complementary and alternative medicine by pregnant women: A literature review. Midwifery. 2011; 27(6): 817-24.

PubMed Abstract | Publisher Full Text

285. Shawahna R, Taha A: Which potential harms and benefits of using ginger in the management of nausea and vomiting of pregnancy should be addressed? a consensual study among pregnant women and gynecologists. BMC Complement Altern Med. 2017; 17(1): 204. PubMed Abstract | Publisher Full Text | Free Full Text

286. Marx W, McCarthy AL, Ried K, et al.: The Effect of a Standardized Ginger Extract on Chemotherapy-Induced Nausea-Related Quality of Life in Patients Undergoing Moderately or Highly Emetogenic Chemotherapy: A Double Blind, Randomized, Placebo Controlled Trial. Nutrients. 2017; 9(8): 867. PubMed Abstract | Publisher Full Text | Free Full Text

287. Albooghobeish M, Ghomeishi A, Adarvishi S, et al.: The Effect of Preoperative Zintoma Capsule on Postoperative Nausea and Vomiting After Laparoscopic Cholecystectomy. Anesth Pain Med. 2018; 8(5): e67132. PubMed Abstract | Publisher Full Text | Free Full Text

288. Soltani E, Jangjoo A, Aghaei MA, et al.: Effects of preoperative administration of ginger (Zingiber officinale Roscoe) on postoperative nausea and vomiting after laparoscopic cholecystectomy.J Tradit Complement Med. 2018; 8(3): 387-90.

PubMed Abstract | Publisher Full Text | Free Full Text

289. Bameshki A, Namaiee $\mathrm{MH}$, Jangjoo A, et al.: Effect of oral ginger on prevention of nausea and vomiting after laparoscopic cholecystectomy: A double-blind, randomized, placebo-controlled trial. Electron Physician. 2018, 10(2): 6354-62.

PubMed Abstract | Publisher Full Text | Free Full Text

290. Tóth B, Lantos T, Hegyi P, et al.: Ginger (Zingiber officinale): An alternative for the prevention of postoperative nausea and vomiting. A meta-analysis. Phytomedicine. 2018; 50: 8-18.

PubMed Abstract | Publisher Full Text

291. Hosseini FS, Adib-Hajbaghery M: Ginger Essence Effect on Nausea and Vomiting After Open and Laparoscopic Nephrectomies. Nurs Midwifery Stud. 2015; 4(2): e28625.

PubMed Abstract | Publisher Full Text | Free Full Text

292. Mandal P, Das A, Majumdar S, et al.: The efficacy of ginger added to ondansetron for preventing postoperative nausea and vomiting in ambulatory surgery. Pharmacognosy Res. 2014; 6(1): 52-7. PubMed Abstract | Publisher Full Text | Free Full Text

293. Nanthakomon T, Pongrojpaw D: The efficacy of ginger in prevention of postoperative nausea and vomiting after major gynecologic surgery. J Med Assoc Thai. 2006; 89 Suppl 4: S130-6. PubMed Abstract

294. Kalava A, Darji SJ, Kalstein A, et al.: Efficacy of ginger on intraoperative and postoperative nausea and vomiting in elective cesarean section patients. Eur J Obstet Gynecol Reprod Biol. 2013; 169(2): 184-8. PubMed Abstract | Publisher Full Text

295. Zeraati H, Shahinfar J, Hesari SI, et al.: The Effect of Ginger Extract on the Incidence and Severity of Nausea and Vomiting After Cesarean Section Under Spinal Anesthesia. Anesth Pain Med. 2016; 6(5): e38943. PubMed Abstract | Publisher Full Text | Free Full Text

296. Lee YR, Shin HS: Effectiveness of Ginger Essential Oil on Postoperative Nausea and Vomiting in Abdominal Surgery Patients. J Altern Complement Med. 2017; 23(3): 196-200. PubMed Abstract | Publisher Full Text

297. Chaiyakunapruk N, Kitikannakorn N, Nathisuwan S, et al.: The efficacy of ginger for the prevention of postoperative nausea and vomiting: A metaanalysis. Am J Obstet Gynecol. 2006; 194(1): 95-9. PubMed Abstract | Publisher Full Text

298. Seidi J, Ebnerasooli S, Shahsawari S, et al.: The Influence of Oral Ginger before Operation on Nausea and Vomiting after Cataract Surgery under General Anesthesia: A double-blind placebo-controlled randomized clinical trial. Electron Physician. 2017; 9(1): 3508-14. PubMed Abstract | Publisher Full Text | Free Full Text

299. Tavlan A, Tuncer S, Erol A, et al.: Prevention of postoperative nausea and vomiting after thyroidectomy: Combined antiemetic treatment with dexamethasone and ginger versus dexamethasone alone. Clin Drug Investig. 2006; 26(4): 209-14. PubMed Abstract | Publisher Full Text

300. Morin AM, Betz O, Kranke P, et al.: [Is Ginger a Relevant Antiemetic for Postoperative Nausea and Vomiting?]. Anasthesiol Intensivmed Notfallmed
Schmerzther. 2004; 39(5): 281-5.

PubMed Abstract | Publisher Full Text

301. Arfeen Z, Owen H, Plummer JL, et al.: A Double-Blind Randomized Controlled Trial of Ginger for the Prevention of Postoperative Nausea and Vomiting. Anaesth Intensive Care. 2019; 23(4): 449-52.

PubMed Abstract | Publisher Full Text

302. Eberhart LHJ, Mayer R, Betz O, et al.: Ginger does not prevent postoperative nausea and vomiting after laparoscopic surgery. Anesth Analg. 2003; 96(4): 995-8, table of contents.

PubMed Abstract | Publisher Full Text

303. Wang SM, Hofstadter MB, Kain ZN: An alternative method to alleviate postoperative nausea and vomiting in children. J Clin Anesth. 1999; 11(3): 231-4.

PubMed Abstract | Publisher Full Text

304. Merritt BA, Okyere CP, Jasinski DM: Isopropyl alcohol inhalation: Alternative treatment of postoperative nausea and vomiting. Nurs Res. 2002; 51(2): $125-8$.

PubMed Abstract | Publisher Full Text

305. Anderson LA, Gross JB: Aromatherapy with peppermint, isopropyl alcohol, or placebo is equally effective in relieving postoperative nausea. J Perianesth Nurs. 2004; 19(1): 29-35. PubMed Abstract | Publisher Full Text

306. Beadle KL, Helbling AR, Love SL, et al.: Isopropyl Alcohol Nasal Inhalation for Nausea in the Emergency Department: A Randomized Controlled Trial. Ann Emerg Med. 2016; 68(1): 1-9.e1. PubMed Abstract | Publisher Full Text

307. Verma DK, Bansal S, Sharma P, et al.: Control of Postoperative Nausea and Vomiting in Oral and Maxillofacial Surgery Patients with Isopropyl Alcohol: A Prospective Randomized Clinical Trial. J Maxillofac Oral Surg. 2018; 17(4): 576-81.

PubMed Abstract | Publisher Full Text | Free Full Text

308. Asay K, Olson C, Donnelly J, et al.: The Use of Aromatherapy in Postoperative Nausea and Vomiting: A Systematic Review.J Perianesth Nurs. 2019; 34(3): 502-16.

PubMed Abstract | Publisher Full Text | Faculty Opinions Recommendation

309. Mcilvoy L, Richmer L, Kramer D, et al.: The Efficacy of Aromatherapy in the Treatment of Postdischarge Nausea in Patients Undergoing Outpatient Abdominal Surgery. J Perianesth Nurs. 2015; 30(5): 383-8. PubMed Abstract | Publisher Full Text

310. Karaman S, Karaman T, Tapar H, et al:: A randomized placebo-controlled study of aromatherapy for the treatment of postoperative nausea and vomiting. Complement Ther Med. 2019; 42: 417-21. PubMed Abstract | Publisher Full Text

311. Brown L, Danda L, Fahey TJ: A Quality Improvement Project to Determine the Effect of Aromatherapy on Postoperative Nausea and Vomiting in a Short-Stay Surgical Population. AORNJ. 2018; 108(4): 361-9. PubMed Abstract | Publisher Full Text

312. Stallings-Welden LM, Doerner $M$, Ketchem $E$, et al: A Comparison of Aromatherapy to Standard Care for Relief of PONV and PDNV in Ambulatory Surgical Patients. J Perianesth Nurs. 2018; 33(2): 116-28. PubMed Abstract | Publisher Full Text

313. Hodge NS, McCarthy MS, Pierce RM: A prospective randomized study of the effectiveness of aromatherapy for relief of postoperative nausea and vomiting. J Perianesth Nurs. 2014; 29(1): 5-11. PubMed Abstract | Publisher Full Text

314. Hines S, Steels E, Chang A, et al.: Aromatherapy for treatment of postoperative nausea and vomiting. Cochrane Database Syst Rev. 2018; 3(3): CD007598.

PubMed Abstract | Publisher Full Text | Free Full Text

315. Hines S, Steels $E$, Chang A, et al:: Aromatherapy for treatment of postoperative nausea and vomiting. Cochrane Database Syst Rev. 2012; (4): CD007598.

PubMed Abstract | Publisher Full Text

316. Lane B, Cannella K, Bowen C, et al.: Examination of the Effectiveness of Peppermint Aromatherapy on Nausea in Women Post C-Section. J Holist Nurs. 2012; 30(2): 90-104. PubMed Abstract | Publisher Full Text

317. Ferruggiari $L$, Ragione $B$, Rich ER, et al.: The effect of aromatherapy on postoperative nausea in women undergoing surgical procedures. J Perianesth Nurs. 2012; 27(4): 246-51. PubMed Abstract | Publisher Full Text

318. Kiberd MB, Clarke SK, Chorney J, et al:: Aromatherapy for the treatment of PONV in children: A pilot RCT. BMC Complement Altern Med. 2016; 16(1): 450. PubMed Abstract | Publisher Full Text | Free Full Text

319. Fan CF, Tanhui E, Joshi S, et al.: Acupressure treatment for prevention of postoperative nausea and vomiting. Anesth Analg. 1997; 84(4): 821-5. PubMed Abstract | Publisher Full Text

320. Alkaissi $\mathrm{A}$, Evertsson $\mathrm{K}$, Johnsson VA, et al:: $\mathrm{P} 6$ acupressure may relieve nausea and vomiting after gynecological surgery: An effectiveness study in $\mathbf{4 1 0}$ women. Can J Anaesth. 2002; 49(10): 1034-9. PubMed Abstract | Publisher Full Text

321. Rusy LM, Hoffman GM, Weisman SJ: Electroacupuncture prophylaxis of postoperative nausea and vomiting following pediatric tonsillectomy with 
or without adenoidectomy. Anesthesiology. 2002; 96(2): 300-5. PubMed Abstract | Publisher Full Text

322. Albooghobeish M, Mohtadi A, Saidkhani V, et al.: Comparison Between Effects of Acupuncture and Metoclopramide on Postoperative Nausea and Vomiting after Gynaecological Laparoscopy: A Randomized Controlled Trial. Anesth Pain Med. 2017; 7(5): e12876. PubMed Abstract | Publisher Full Text | Free Full Text

323. Constantine FC, Matarasso A: Putting It All Together: Recommendations for Improving Pain Management in Body Contouring. Plast Reconstr Surg. 2014 134(4 Suppl 2): 113S-119S.

PubMed Abstract | Publisher Full Text

324. Larson JD, Gutowski KA, Marcus BC, et al.: The effect of electroacustimulation on postoperative nausea, vomiting, and pain in outpatient plastic surgery patients: A prospective, randomized, blinded, clinical trial. Plast Reconstr Surg. 2010; 125(3): 989-94. PubMed Abstract | Publisher Full Text

325. Lee $A$, Done ML: The use of nonpharmacologic techniques to prevent postoperative nausea and vomiting: A meta-analysis. Anesth Analg. 1999; 88(6): 1362-9.

PubMed Abstract | Publisher Full Text

326. Lu C, Du JY, Fang JQ, et al.: [The curative effect observation of different frequency of TEAS combined with wristband pressing on Neiguan (PC 6) for nausea and vomiting after laparoscopic cholecystectomy]. Zhongguo Zhen jiu. 2019; 39(1): 9-15.

PubMed Abstract | Publisher Full Text | Faculty Opinions Recommendation

327. Gan TJ, liao KR, Zenn M, et al:: A randomized controlled comparison of electro-acupoint stimulation or ondansetron versus placebo for the prevention of postoperative nausea and vomiting. Anesth Analg. 2004; 99(4): 1070-5, table of contents. PubMed Abstract | Publisher Full Text

328. Lee A, Fan LT: Stimulation of the wrist acupuncture point P6 for preventing postoperative nausea and vomiting. Cochrane Database Syst Rev. 2009; (2): CD003281.

PubMed Abstract | Publisher Full Text | Free Full Text

329. Gouveia F, Oliveira C, Losa N: Acupuncture in the Management of Intraoperative Nausea and Vomiting. J Acupunct Meridian Stud. 2016; 9(6): $325-9$

PubMed Abstract | Publisher Full Text

330. Moore CB, Hickey AH: Increasing Access to Auricular Acupuncture for Postoperative Nausea and Vomiting. J Perianesth Nurs. 2017; 32(2): 96-105. PubMed Abstract | Publisher Full Text

331. Carr KL, Johnson FE, Kenaan CA, et al.: Effects of P6 stimulation on postoperative nausea and vomiting in laparoscopic cholecystectomy patients. J Perianesth Nurs. 2015; 30(2): 143-50. PubMed Abstract | Publisher Full Text

332. Farhadi K, Choubsaz M, Setayeshi K, et al.: The Effectiveness of Dry-Cupping in Preventing Post-Operative Nausea and Vomiting by P6 Acupoint Stimulation: A Randomized Controlled Trial. Medicine (Baltimore). 2016; 95(38): e4770.

PubMed Abstract | Publisher Full Text | Free Full Text

333. Lee S, Lee MS, Choi DH, et al.: Electroacupuncture on PC6 prevents opioidinduced nausea and vomiting after laparoscopic surgery. Chin J Integr Med. 2013; 19(4): 277-81.

PubMed Abstract | Publisher Full Text

334. Ünülü M, Kaya N: The Effect of Neiguan Point (P6) Acupressure With Wristband on Postoperative Nausea, Vomiting, and Comfort Level: A Randomized Controlled Study. J Perianesth Nurs. 2018; 33(6): 915-27. PubMed Abstract | Publisher Full Text

335. Stott A: Examining the efficacy of stimulating the PC6 wrist acupuncture point for preventing postoperative nausea and vomiting: A Cochrane review summary. Int J Nurs Stud. 2016; 64: 139-41. PubMed Abstract | Publisher Full Text

336. Stoicea N, Gan TJ, Joseph N, et al.: Alternative Therapies for the Prevention of Postoperative Nausea and Vomiting. Front Med (Lausanne). 2015; 2: 87. PubMed Abstract | Publisher Full Text | Free Full Text

337. Kwon JH, Shin Y, Juon HS: Effects of Nei-Guan (P6) Acupressure Wristband: On Nausea, Vomiting, and Retching in Women After Thyroidectomy. Cancer Nurs. 2016; 39(1): 61-6.

PubMed Abstract | Publisher Full Text

338. Sun R, Dai W, Liu Y, et al.: Non-needle acupoint stimulation for prevention of nausea and vomiting after breast surgery: A meta-analysis. Medicine (Baltimore). 2019; 98(10): e14713. PubMed Abstract | Publisher Full Text | Free Full Text | Faculty Opinions Recommendation

339. Li S, Zheng M, Wu W, et al.: Effects of Electroacupuncture Administered 24 hours Prior to Surgery on Postoperative Nausea and Vomiting and Pain in Patients Undergoing Gynecologic Laparoscopic Surgery: A Feasibility Study. Explore (NY). 2017; 13(5): 313-8. PubMed Abstract | Publisher Full Text

340. Hofmann D, Murray C, Beck J, et al.: Acupressure in Management of Postoperative Nausea and Vomiting in High-Risk Ambulatory Surgical Patients. J Perianesth Nurs. 2017; 32(4): 271-8. PubMed Abstract | Publisher Full Text

341. Oh H, Kim BH: Comparing Effects of Two Different Types of Nei-Guan
Acupuncture Stimulation Devices in Reducing Postoperative Nausea and Vomiting. J Perianesth Nurs. 2017: 32(3): 177-87.

PubMed Abstract | Publisher Full Text

342. Feng C, Popovic J, Kline R, et al.: Auricular Acupressure in the Prevention of Postoperative Nausea and Emesis A Randomized Controlled Trial. Bull Hosp to Dis (2013). 2017; 75(2): 114-8.

PubMed Abstract

343. Weeks EM, Trinca J, Zheng Z: Knowledge of and willingness to try acupuncture for postoperative nausea and vomiting: An Australian survey of surgical patients. Acupunct Med. 2017; 35(5): 345-51.

PubMed Abstract | Publisher Full Text

344. Liu Y, Wang M, Li Q, et al.: [Impacts of transcutaneous acupoint electric stimulation on the postoperative nausea and vomiting and plasma 5-HT concentration after cesarean section]. Zhongguo Zhen Jiu. 2015; 35(10): 1039-43. PubMed Abstract

345. Lin M, Xiong X, Wei W: Effect of auricular point therapy combined with transcutaneous electrical acupoint stimulation on prevention of postoperative nausea and vomiting in patients undergoing partial breast resection. J Pract Med. 2015; 31: 1858-60.

346. Pan F, Gong H, He B, et al.: Preventive and therapeutic effects of different acupoints and stimulating methods on nausea and vomiting after breast surgery. J New Chin Med. 2014; 46: 169-71.

347. Wang Z, Zeng F, Qian B: Effects of transcutaneous electrical acupoint stimulation on postoperative recovery quality after breast cancer surgery. Med J West China. 2017; 29: 1233-6.

348. Zhou W, Hu L, Ye J, et al.: Effect of percutaneous acupoint electrical stimulation on adverse reactions after modified radical mastectomy for breast cancer. Chin J Rural Med Pharm. 2017; 24: 27-8.

349. Quinlan-Woodward J, Gode A, Dusek JA, et al.: Assessing the Impact of Acupuncture on Pain, Nausea, Anxiety, and Coping in Women Undergoing a Mastectomy. Oncol Nurs Forum. 2016; 43(6): 725-32. PubMed Abstract | Publisher Full Text

350. Pouy S, Etebarian A, Azizi-Qadikolaee A, et al:: The effect of acupuncture on postoperative pain, nausea and vomiting after pediatric tonsillectomy: A systematic review. Int J Adolesc Med Health. 2019.

PubMed Abstract | Publisher Full Text | Faculty Opinions Recommendation

351. Shin HC, Kim JS, Lee SK, et al.: The effect of acupuncture on postoperative nausea and vomiting after pediatric tonsillectomy: A meta-analysis and systematic review. Laryngoscope. 2016; 126(8): 1761-7. PubMed Abstract | Publisher Full Text

352. Özmert S, Salman N, Sever F, et al.: Acupuncture as an Antiemetic in Children who Underwent Adenoidectomy and/or Tonsillectomy. Turk J Anaesthesiol Reanim. 2016; 44(1): 7-12 PubMed Abstract | Publisher Full Text | Free Full Text

353. Liodden I, Howley M, Grimsgaard AS, et al.: Perioperative Acupuncture and Postoperative Acupressure Can Prevent Postoperative Vomiting following Paediatric Tonsillectomy Or Adenoidectomy: A Pragmatic Randomised Controlled Trial. Acupunct Med. 2018; 29(1): 9-15. PubMed Abstract | Publisher Full Text

354. Shin BC: Acupuncture for post- tonsillectomy pain: evidence from a recent randomized clinical trial. Longhua Chinese Medicine. 2018; Icm.amegroups.com. Publisher Full Text

355. Ochi JW, Richardson AC: Intraoperative pediatric acupuncture is widely accepted by parents. Int J Pediatr Otorhinolaryngol. 2018; 110: 12-5. PubMed Abstract | Publisher Full Text

356. Ghezelbash S, Khosravi M: Acupressure for nausea-vomiting and fatigue management in acute lymphoblastic leukemia children.J Nurs Midwifery Sci. 2017; 4(3): 75-81. Publisher Full Text

357. Goel H, Mathur S, Sandhu M, et al.: Effect of Low-level LASER Therapy on P6 Acupoint to Control Gag Reflex in Children: A Clinical Trial. J Acupunct Meridian Stud. 2017; 10(5): 317-23.

PubMed Abstract | Publisher Full Text

358. Butkovic D, Toljan S, Matolic M, et al.: Comparison of laser acupuncture and metoclopramide in PONV prevention in children. Paediatr Anaesth. 2005; 15(1): $37-40$.

PubMed Abstract | Publisher Full Text

359. Barsoum G, Perry EP, Fraser IA: Postoperative nausea is relieved by acupressure. J R Soc Med. 1990; 83(2): 86-9. PubMed Abstract | Publisher Full Text | Free Full Text

360. Varejão CdS, Santo FHdE: Laser Acupuncture for Relieving Nausea and Vomiting in Pediatric Patients Undergoing Chemotherapy: A Single-Blind Randomized Clinical Trial. J Pediatr Oncol Nurs. 2018; 36(1): 44-54. PubMed Abstract | Publisher Full Text

361. Martin CS, Deverman SE, Norvell DC, et al.: Randomized trial of acupuncture with antiemetics for reducing postoperative nausea in children. Acta Anaesthesiol Scand. 2019; 63(3): 292-7. PubMed Abstract | Publisher Full Text

362. Hasheminasab FS, Ayati MH: A review on the efficacy of acupuncture to prevent nausea and vomiting after strabismus surgery. Trad Integr Med. 2017; 2(2): 90-7 Reference Source

363. Yilmaz Sahin S, Iyigun E, Can MF: Effect of acupressure application to the P6 acupoint before laparoscopic cholecystectomy on postoperative 
nausea-vomiting: A randomized controlled clinical study. Int J Nurs Stud. 2018; 87: 40-8.

PubMed Abstract | Publisher Full Text

364. Liu WH, Hao Y, Han YJ, et al.: Analysis and Thoughts about the Negative Results of International Clinical Trials on Acupuncture. Evid Based Complement Alternat Med. 2015; 2015: 671242. PubMed Abstract | Publisher Full Text | Free Full Text

365. Christensen KA, Gosse BJ, Hildebrand C, et al.: Acupuncture-Associated Vasovagal Response: Revised Terminology and Hospital Experience. Med Acupunct. 2017; 29(6): 366-76. PubMed Abstract | Publisher Full Text | Free Full Text

366. Gilbert RT, Farish N, Bergland E, et al.: The Use of Short-Term Acupressure to Prevent Long-Term PONV: Was This a Case of Too Little, Too Late? J Perianesth Nurs. 2017; 32(5): 445-52. PubMed Abstract | Publisher Full Text

367. Jernigan AM, Chen CCG, Sewell C: A randomized trial of chewing gum to prevent postoperative ileus after laparotomy for benign gynecologic surgery. Int J Gynaecol Obstet. 2014; 127(3): 279-82. PubMed Abstract | Publisher Full Text

368. Darvall JN, Handscombe M, Leslie K: Chewing gum for the treatment of postoperative nausea and vomiting: A pilot randomized controlled trial. $\mathrm{Br}$ Anaesth. 2017; 118(1): 83-9. PubMed Abstract | Publisher Full Text

369. Ciardulli A, Saccone G, Di Mascio D, et al.: Chewing gum improves postoperative recovery of gastrointestinal function after cesarean delivery: A systematic review and meta-analysis of randomized trials. J Matern Fetal Neonatal Med. 2018; 31(14): 1924-32. PubMed Abstract | Publisher Full Text

370. Xu C, Peng J, Liu S, et al.: Effect of chewing gum on gastrointestinal function after gynecological surgery: A systematic literature review and metaanalysis. J Obstet Gynaecol Res. 2018; 44(5): 936-43. PubMed Abstract | Publisher Full Text

371. Ge B, Zhao H, Lin R, et al:: Influence of gum-chewing on postoperative bowel activity after laparoscopic surgery for gastric cancer: A randomized controlled trial. Medicine (Baltimore). 2017; 96(13): e6501. PubMed Abstract | Publisher Full Text | Free Full Text

372. Mason KP: Pediatric Sedation Outside of the Operating Room: A Multispecialty International Collaboration. New York: Springer. 2015. Publisher Full Text

373. Hole J, Hirsch M, Ball E, et al.: Music as an aid for postoperative recovery in adults: A systematic review and meta-analysis. Lancet. 2015; 386(10004): 1659-71.

PubMed Abstract | Publisher Full Text

374. Flanagan DA, Kerin A: How is intraoperative music therapy beneficial to adult patients undergoing general anesthesia? A systematic review. Anesthesia eJ. 2017; 5(2): 5-13. Reference Source

375. Nilsson U, Rawal N, Uneståhl LE, et al.: Improved recovery after music and therapeutic suggestions during general anaesthesia: A double-blind randomised controlled trial. Acta Anaesthesiol Scand. 2001; 45(7): 812-7. PubMed Abstract | Publisher Full Text

376. Allred KD, Byers JF, Sole ML: The effect of music on postoperative pain and anxiety. Pain Manag Nurs. 2010; 11(1): 15-25. PubMed Abstract | Publisher Full Text

377. Kahloul M, Mhamdi S, Nakhli MS, et al.: Effects of music therapy under general anesthesia in patients undergoing abdominal surgery. Libyan J Med. 2017: 12(1): 1260886

PubMed Abstract | Publisher Full Text | Free Full Text

378. Palmer JB, Lane D, Mayo D, et al.: Effects of Music Therapy on Anesthesia Requirements and Anxiety in Women Undergoing Ambulatory Breast Surgery for Cancer Diagnosis and Treatment: A Randomized Controlled Trial. J Clin Oncol. 2015; 33(28): 3162-8. PubMed Abstract | Publisher Full Text | Free Full Text

379. Bradt J, Dileo C, Shim M: Music interventions for preoperative anxiety. Cochrane Database Syst Rev. 2013; (6): CD006908.

PubMed Abstract | Publisher Full Text

380. van der Heijden MJE, Oliai Araghi S, van Dijk M, et al.: The Effects of Perioperative Music Interventions in Pediatric Surgery: A Systematic Review and Meta-Analysis of Randomized Controlled Trials. PLoS One. 2015; 10(8): e0133608.

PubMed Abstract | Publisher Full Text | Free Full Text

381. Sin WM, Chow KM: Effect of Music Therapy on Postoperative Pain Management in Gynecological Patients: A Literature Review. Pain Manag Nurs. 2015; 16(6): 978-87. PubMed Abstract | Publisher Full Text

382. Manyande A, Cyna AM, Yip P, et al.: Non-pharmacological interventions for assisting the induction of anaesthesia in children. Cochrane Database Syst Rev. 2015; (7): CD006447. PubMed Abstract | Publisher Full Text

383. Good M, Anderson GC, Ahn S, et al:: Relaxation and music reduce pain following intestinal surgery. Res Nurs Health. 2005; 28(3): 240-51. PubMed Abstract | Publisher Full Text

384. Good M, Anderson GC, Stanton-Hicks M, et al.: Relaxation and music reduce pain after gynecologic surgery. Pain Management Nursing. 2002; 3(2): 61-70. PubMed Abstract | Publisher Full Text

385. Binns-Turner PG, Wilson LL, Pryor ER, et al.: Perioperative music and its effects on anxiety, hemodynamics, and pain in women undergoing mastectomy. AANA J. 2011; 79(4 Suppl): S21-7.

PubMed Abstract

386. Bringman $\mathrm{H}$, Giesecke $\mathrm{K}$, Thörne $\mathrm{A}$, et al.: Relaxing music as pre-medication before surgery: A randomised controlled trial. Acta Anaesthesiol Scand. 2009; 53(6): 759-64 PubMed Abstract | Publisher Full Text

387. Madson AT, Silverman Ml: The Effect of Music Therapy on Relaxation, Anxiety, Pain Perception, and Nausea in Adult Solid Organ Transplant Patients. J Music Ther. 2010; 47(3): 220-32. PubMed Abstract | Publisher Full Text

388. Jayaraman L, Sharma S, Sethi N, et al.: Does intraoperative music therapy or positive therapeutic suggestions during general anaesthesia affect the postoperative outcome? - A double blind randomised controlled. Indian J. Anaesth. 2006; 50(4): 258-61. Reference Source

389. Cetinkaya F: The effects of listening to music on the postoperative nausea and vomiting. Complement Ther Clin Pract. 2019; 35: 278-83. PubMed Abstract | Publisher Full Text

390. Gokçek E, Kaydu A: The effects of music therapy in patients undergoing septorhinoplasty surgery under general anesthesia. Braz J Otorhinolaryngol. 2019; S1808-8694(18)30606-2. PubMed Abstract | Publisher Full Text

391. Kurdi MS, Gasti V: Intraoperative Meditation Music as an Adjunct to Subarachnoid Block for the Improvement of Postoperative Outcomes Following Cesarean Section: A Randomized Placebo-controlled Comparative Study. Anesth Essays Res. 2018; 12(3): 618-24. PubMed Abstract | Publisher Full Text | Free Full Text

392. Çankaya A, Saritaş S: Effect of Classic Foot Massage on Vital Signs, Pain, and Nausea/Vomiting Symptoms After Laparoscopic Cholecystectomy. Surg Laparosc Endosc Percutan Tech. 2018; 28(6): 359-65. PubMed Abstract | Publisher Full Text

393. Johns DE, Gerling V, Pasker-de Jong PCM: Ice pops in the recovery room: Effects on postoperative nausea and vomiting. Br J Anaesth. 2017; 118(4): 637-8. PubMed Abstract | Publisher Full Text

394. $\mathrm{Li} \mathrm{G}$, Lin L, Dai F, et al.: Muscular tissue oxygen saturation during robotic hysterectomy and postoperative nausea and vomiting: Exploring the potential therapeutic thresholds. J Clin Monit Comput. 2019; 33(4): 597-604. PubMed Abstract | Publisher Full Text | Faculty Opinions Recommendation

395. Guo W, Ding J, Jin X, et al.: Effect of cerebral oxygen saturation on postoperative nausea and vomiting in female laparoscopic surgery patients. Medicine (Baltimore). 2017; 96(41): e8275 PubMed Abstract | Publisher Full Text | Free Full Text

396. Alghanem SM, Massad IM, Rashed EM, et al.: Optimization of anesthesia antiemetic measures versus combination therapy using dexamethasone or ondansetron for the prevention of postoperative nausea and vomiting Surg Endosc. 2010; 24(2): 353-8. PubMed Abstract | Publisher Full Text

397. Tang J, Chen X, White PF, et al.: Antiemetic prophylaxis for office-based surgery: Are the 5-HT3 receptor antagonists beneficial? Anesthesiology. 2003; 98(2): 293-8. PubMed Abstract | Publisher Full Text

398. Eberhart LHJ, Mauch M, Morin AM, et al.: Impact of a multimodal anti-emetic prophylaxis on patient satisfaction in high-risk patients for postoperative nausea and vomiting. Anaesthesia. 2002; 57(10): 1022-7. PubMed Abstract | Publisher Full Text

399. Pym A, Ben-Menachem E: The effect of a multifaceted postoperative nausea and vomiting reduction strategy on prophylaxis administration amongst higher-risk adult surgical patients. Anaesth Intensive Care. 2018; 46(2): 185-9. PubMed Abstract | Publisher Full Text

400. Tabrizi S, Malhotra V, Turnbull ZA, et al.: Implementation of Postoperative Nausea and Vomiting Guidelines for Female Adult Patients Undergoing Anesthesia During Gynecologic and Breast Surgery in an Ambulatory Setting. J Perianesth Nurs. 2019; 34(4): 851-60. PubMed Abstract | Publisher Full Text | Faculty Opinions Recommendation

401. Walldén J, Flodin J, Hultin M: Validation of a prediction model for postdischarge nausea and vomiting after general anaesthesia in a cohort of Swedish ambulatory surgery patients. Eur J Anaesthesiol. 2016; 33(10): 743-9. PubMed Abstract | Publisher Full Text

402. King $A B$, Spann $M D$, Jablonski $P$, et al.: An enhanced recovery program for bariatric surgical patients significantly reduces perioperative opioid consumption and postoperative nausea. Surg Obes Relat Dis. 2018; 14(6): 849-56. PubMed Abstract | Publisher Full Text

403. Scuderi PE, James RL, Harris L, et al.: Multimodal Antiemetic Management Prevents Early Postoperative Vomiting After Outpatient Laparoscopy. Anesth Analg. 2000; 91(6): 1408-14. PubMed Abstract | Publisher Full Text

404. Bruderer U, Fisler A, Steurer MP, et al.: Post-discharge nausea and vomiting after total intravenous anaesthesia and standardised PONV prophylaxis for ambulatory surgery. Acta Anaesthesiol Scand. 2017; 61(7): 758-66. PubMed Abstract | Publisher Full Text

405. Bergese SD, Antor MA, Uribe AA, et al.: Triple Therapy with Scopolamine, Ondansetron, and Dexamethasone for Prevention of Postoperative Nausea 
and Vomiting in Moderate to High-Risk Patients Undergoing Craniotomy Under General Anesthesia: A Pilot Study. Front Med (Lausanne). 2015; 2: 40. PubMed Abstract | Publisher Full Text | Free Full Text

406. Henzi I, Walder B, Tramèr MR: Dexamethasone for the Prevention of Postoperative Nausea and Vomiting: A Quantitative Systematic Review. Anesth Analg. 2000; 90(1): 186-94. PubMed Abstract | Publisher Full Text

407. Singh LD, Singh YN, Singh NR, et al:: A comparative study between ramosetron and granisetron for the prevention of postoperative nausea and vomiting after laparoscopic cholecystectomy. J Med Soc. 2013; 27(3): 194-198. Publisher Full Text

408. Chu CC, Shieh JP, Tzeng JI, et al.: The prophylactic effect of haloperidol plus dexamethasone on postoperative nausea and vomiting in patients undergoing laparoscopically assisted vaginal hysterectomy. Anesth Analg. 2008; 106(5): 1402-6. PubMed Abstract | Publisher Full Text

409. Habib AS, El-Moalem HE, Gan TJ: The efficacy of the 5-HT3 receptor antagonists combined with droperidol for PONV prophylaxis is similar to their combination with dexamethasone. A meta-analysis of randomized controlled trials. Can J Anesth. 2004; 51(4): 311-9. PubMed Abstract | Publisher Full Text

410. Maddali MM, Mathew J, Fahr J, et al.: Postoperative nausea and vomiting in diagnostic gynaecological laparoscopic procedures: Comparison of the efficacy of the combination of dexamethasone and metoclopramide with that of dexamethasone and ondansetron. J Postgrad Med. 2003; 49(4): 302-6. PubMed Abstract

411. Gan TJ, Franiak R, Reeves J: Ondansetron orally disintegrating tablet versus placebo for the prevention of postdischarge nausea and vomiting after ambulatory surgery. Anesth Analg. 2002; 94(5): 1199-200. PubMed Abstract | Publisher Full Text

412. Dewinter G, Staelens $W$, Veef E, et al.: Simplified algorithm for the prevention of postoperative nausea and vomiting: A before-and-after study. $\mathrm{BrJ}$ Anaesth. 2018; 120(1): 156-63. PubMed Abstract | Publisher Full Text

413. Kumar A, Solanki SL, Gangakhedkar GR, et al.: Comparison of palonosetron and dexamethasone with ondansetron and dexamethasone for postoperative nausea and vomiting in postchemotherapy ovarian cancer surgeries requiring opioid-based patient-controlled analgesia: A randomised, double-blind, active controlled study. Indian J Anaesth. 2018; 62(10): 773-9.

ubMed Abstract | Publisher Full Text | Free Full Text

414. Ryu JH, Jeon YT, Min B, et al.: Effects of palonosetron for prophylaxis of postoperative nausea and vomiting in high-risk patients undergoing tota knee arthroplasty: A prospective, randomized, double-blind, placebocontrolled study. PLoS One. 2018; 13(5): e0196388. PubMed Abstract | Publisher Full Text | Free Full Text

415. Tramèr MR: A rational approach to the control of postoperative nausea and vomiting: Evidence from systematic reviews. Part I. Efficacy and harm of antiemetic interventions, and methodological issues. Acta Anaesthesiol Scand. 2001; 45(1): 4-13. PubMed Abstract | Publisher Full Text

416. Gan TJ, Coop A, Philip BK: A Randomized, Double-Blind Study of Granisetron Plus Dexamethasone Versus Ondansetron Plus Dexamethasone to Prevent Postoperative Nausea and Vomiting in Patients Undergoing Abdominal Hysterectomy. Anesth Analg. 2005; 101(5): 1323-9. PubMed Abstract | Publisher Full Text

417. White PF, Watcha MF: Postoperative Nausea and Vomiting: Prophylaxis Versus Treatment. Anesth Analg. 1999; 89(6): 1337. PubMed Abstract | Publisher Full Text

418. Gillmann HJ, Wasilenko S, Züger J, et al.: Standardised electronic algorithms for monitoring prophylaxis of postoperative nausea and vomiting. Arch Med Sci. 2019; 15(2): 408-15.

PubMed Abstract | Publisher Full Text | Free Full Text

419. Habib AS, Reuveni J, Taguchi A, et al.: A comparison of ondansetron with promethazine for treating postoperative nausea and vomiting in patients who received prophylaxis with ondansetron: A retrospective database analysis. Anesth Analg. 2007; 104(3): 548-51. PubMed Abstract | Publisher Full Text

420. Habib AS, Gan TJ: The effectiveness of rescue antiemetics after failure of prophylaxis with ondansetron or droperidol: A preliminary report. J Clin Anesth. 2005; 17(1): 62-5. PubMed Abstract | Publisher Full Text

421. Brookes CD, Berry J, Rich J, et al.: Multimodal protocol reduces postoperative nausea and vomiting in patients undergoing Le Fort I osteotomy. J Oral Maxillofac Surg. 2015; 73(3): 324-32. PubMed Abstract | Publisher Full Text | Free Full Text

422. Mayeur C, Robin E, Kipnis E, et al.: Impact of a prophylactic strategy on the incidence of nausea and vomiting after general surgery. Ann Fr Anesth Reanim. 2012; 31(2): e53-e57. PubMed Abstract | Publisher Full Text

423. Myklejord $D$ J, Yao $L$, Liang $H$, et al.: Consensus guideline adoption for managing postoperative nausea and vomiting. WMJ. 2012; 111(5): 207-13; quiz 214. PubMed Abstract

424. Yazbeck-Karam VG, Siddik-Sayyid SM, Barakat HB, et al.: Haloperidol Versus
Ondansetron for Treatment of Established Nausea and Vomiting Following General Anesthesia: A Randomized Clinical Trial. Anesth Analg. 2017; 124(2): 438-44.

PubMed Abstract | Publisher Full Text

425. Hu X, Fang T, Gong L: Higher dose of palonosetron versus lower dose of palonosetron plus droperidol to prevent postoperative nausea and vomiting after eye enucleation and orbital hydroxyapatite implant surgery: A randomized, double-blind trial. Drug Des Devel Ther. 2017; 11: 1465-72. PubMed Abstract | Publisher Full Text | Free Full Text

426. Rüsch D, Eberhart LHJ, Wallenborn J, et al.: Nausea and vomiting after surgery under general anesthesia: An evidence-based review concerning risk assessment, prevention, and treatment. Dtsch Arztebl Int. 2010; 107(42): 733-41. PubMed Abstract | Publisher Full Text | Free Full Text

427. Rüsch D, Arndt C, Martin $\mathrm{H}$, et al.: The addition of dexamethasone to dolasetron or haloperidol for treatment of established postoperative nausea and vomiting. Anaesthesia. 2007; 62(8): 810-7. PubMed Abstract | Publisher Full Text

428. Therneau IW, Martin EE, Sprung J, et al.: The Role of Aprepitant in Prevention of Postoperative Nausea and Vomiting After Bariatric Surgery. Obes Surg. 2018; 28(1): 37-43. PubMed Abstract | Publisher Full Text

429. Trimas SJ, Trimas MD: Use of Aprepitant and Factors Associated With Incidence of Postoperative Nausea and Vomiting in Patients Undergoing Facial Plastic Surgery. JAMA Facial Plast Surg. 2015; 17(4): 251-5. PubMed Abstract | Publisher Full Text

430. Thomas JS, Maple IK, Norcross W, et al.: Preoperative Risk Assessment to Guide Prophylaxis and Reduce the Incidence of Postoperative Nausea and Vomiting. J Perianesth Nurs. 2019; 34(1): 74-85. PubMed Abstract | Publisher Full Text

431. Fearon JA, Dimas V, Ditthakasem K, et al: A Randomized Controlled Trial of Oral Versus Intravenous Administration of a Nonnarcotic Analgesia Protocol Following Pediatric Craniosynostosis Corrections on Nausea and Vomiting Rates. J Craniofac Surg. 2015; 26(6): 1951-3. PubMed Abstract | Publisher Full Text

432. White PF: What are the advantages of non-opioid analgesic techniques in the management of acute and chronic pain? Expert Opin Pharmacother. 2017; 18(4): 329-33. PubMed Abstract | Publisher Full Text

433. Gärtner R, Kroman N, Callesen T, et al:: Multimodal prevention of pain, nausea and vomiting after breast cancer surgery. Minerva Anestesiol. 2010; 76(10): 805-13. PubMed Abstract

434. Tan M, Law LSC, Gan T]: Optimizing pain management to facilitate Enhanced Recovery After Surgery pathways. Can J Anaesth. 2015; 62(2): 203-18. PubMed Abstract | Publisher Full Text

435. Azhar RA, Bochner B, Catto J, et al.: Enhanced Recovery after Urological Surgery: A Contemporary Systematic Review of Outcomes, Key Elements, and Research Needs. Eur Urol. 2016; 70(1): 176-87. PubMed Abstract | Publisher Full Text | Free Full Text

436. Ziemann-Gimmel P, Goldfarb AA, Koppman J, et al.: Opioid-free total intravenous anaesthesia reduces postoperative nausea and vomiting in bariatric surgery beyond triple prophylaxis. Br J Anaesth. 2014; 112(5): 906-11. PubMed Abstract | Publisher Full Text

437. Peyton PJ, Wu CY: Nitrous Oxide-related Postoperative Nausea and Vomiting Depends on Duration of Exposure. Anesthesiology. 2014; 120(5): 1137-45. PubMed Abstract | Publisher Full Text

438. Myles PS, Chan MTV, Kasza J, et al.: Severe Nausea and Vomiting in the Evaluation of Nitrous Oxide in the Gas Mixture for Anesthesia II Trial. Anesthesiology. 2016; 124(5): 1032-40. PubMed Abstract | Publisher Full Text

439. Janhunen $L$, Tammisto $T$ : Postoperative vomiting after different modes of general anaesthesia. Ann Chir Gynaecol Fenn. 1972; 61(3): 152-9. PubMed Abstract

440. Cheng CR, Sessler DI, Apfel CC: Does Neostigmine Administration Produce a Clinically Important Increase in Postoperative Nausea and Vomiting? Anesth Analg. 2005; 101(5): 1349-55. PubMed Abstract | Publisher Full Text | Free Full Text

441. Lee $\mathrm{OH}$, Choi $\mathrm{G}$, Kang $\mathrm{H}$, et al.: Effects of sugammadex vs. pyridostigmineglycopyrrolate on post-operative nausea and vomiting: Propensity score matching. Acta Anaesthesiol Scand. 2017; 61(1): 39-45. PubMed Abstract | Publisher Full Text

442. Yağan O, Taş N, Mutlu T, et al.: Comparison of the effects of sugammadex and neostigmine on postoperative nausea and vomiting. Braz J Anesthesiol. 2017; 67(2): 147-52. PubMed Abstract | Publisher Full Text

443. Tas Tuna A, Palabiyik O, et al.: Does Sugammadex Administration Affect Postoperative Nausea and Vomiting After Laparoscopic Cholecystectomy: A Prospective, Double-Blind, Randomized Study. Surg Laparosc Endosc Percutan Tech. 2017; 27(4): 237-40. PubMed Abstract | Publisher Full Text

444. Manahan MA, Johnson DJ, Gutowski KA, et al.: Postoperative Nausea and Vomiting with Plastic Surgery: A Practical Advisory to Etiology, Impact, and Treatment. Plast Reconstr Surg. 2018; 141(1): 214-22. PubMed Abstract | Publisher Full Text 


\section{Open Peer Review}

\section{Current Peer Review Status:}

\section{Editorial Note on the Review Process}

Faculty Reviews are review articles written by the prestigious Members of Faculty Opinions. The articles are commissioned and peer reviewed before publication to ensure that the final, published version is comprehensive and accessible. The reviewers who approved the final version are listed with their names and affiliations.

\section{The reviewers who approved this article are:}

\section{Version 1}

\section{Joseph V. Pergolizzi}

Naples Anesthesia and Pain Associates - Pain Medicine, Naples, FL, USA

Competing Interests: No competing interests were disclosed.

\section{Patrice Forget (iD)}

Department of Anaesthesia, University of Aberdeen, Aberdeen, AB25 2ZD, UK

Competing Interests: No competing interests were disclosed.

The benefits of publishing with F1000Research:

- Your article is published within days, with no editorial bias

- You can publish traditional articles, null/negative results, case reports, data notes and more

- The peer review process is transparent and collaborative

- Your article is indexed in PubMed after passing peer review

- Dedicated customer support at every stage

For pre-submission enquiries, contact research@f1000.com 